Review

\title{
Neuroimaging Correlates of Cognitive Dysfunction in Adults with Multiple Sclerosis
}

\author{
Maria Petracca ${ }^{1,+}$, Giuseppe Pontillo ${ }^{2,3,+}{ }^{-}$, Marcello Moccia ${ }^{1}\left(\mathbb{D}\right.$, Antonio Carotenuto ${ }^{1}$, Sirio Cocozza ${ }^{2}$, \\ Roberta Lanzillo ${ }^{1, *} \mathbb{\infty}$, Arturo Brunetti ${ }^{2, \ddagger}$ and Vincenzo Brescia Morra ${ }^{1, \ddagger}$ \\ 1 Department of Neurosciences, Reproductive and Odontostomatological Sciences, University of Naples \\ "Federico II", 80131 Naples, Italy; maria.petracca@unina.it (M.P.); moccia.marcello@gmail.com (M.M.); \\ carotenuto.antonio87@gmail.com (A.C.); vincenzo.bresciamorra2@unina.it (V.B.M.) \\ 2 Department of Advanced Biomedical Sciences, University of Naples "Federico II", 80131 Naples, Italy; \\ giuseppe.pon@gmail.com (G.P.); siriococozza@hotmail.it (S.C.); brunetti@unina.it (A.B.) \\ 3 Department of Electrical Engineering and Information Technology, University of Naples "Federico II", \\ 80125 Naples, Italy \\ * Correspondence: robertalanzillo@libero.it; Tel.: +39-081-746-3764; Fax: +39-081-546-3663 \\ + Both authors equally contributed to the manuscript as co-first authors. \\ $\ddagger$ Both authors equally contributed to the manuscript as co-last authors.
}

check for

updates

Citation: Petracca, M.; Pontillo, G.; Moccia, M.; Carotenuto, A.; Cocozza, S.; Lanzillo, R.; Brunetti, A.; Brescia Morra, V. Neuroimaging Correlates of Cognitive Dysfunction in Adults with Multiple Sclerosis. Brain Sci. 2021, 11, 346. https://doi.org/10.3390/ brainsci11030346

Academic Editor: Jordi

A. Matias-Guiu

Received: 24 February 2021

Accepted: 4 March 2021

Published: 9 March 2021

Publisher's Note: MDPI stays neutral with regard to jurisdictional claims in published maps and institutional affiliations.

Copyright: (C) 2021 by the authors. Licensee MDPI, Basel, Switzerland. This article is an open access article distributed under the terms and conditions of the Creative Commons Attribution (CC BY) license (https:/ / creativecommons.org/licenses/by/ $4.0 /)$.

\begin{abstract}
Cognitive impairment is a frequent and meaningful symptom in multiple sclerosis (MS), caused by the accrual of brain structural damage only partially counteracted by effective functional reorganization. As both these aspects can be successfully investigated through the application of advanced neuroimaging, here, we offer an up-to-date overview of the latest findings on structural, functional and metabolic correlates of cognitive impairment in adults with MS, focusing on the mechanisms sustaining damage accrual and on the identification of useful imaging markers of cognitive decline.
\end{abstract}

Keywords: cognitive dysfunction; neuroimaging; multiple sclerosis; magnetic resonance imaging; positron emission tomography; sodium; atrophy

\section{Introduction}

Cognitive impairment, which can be present from the very early or even preclinical stages of the disease [1,2], has been reported in 34 to $65 \%$ of adults with multiple sclerosis (MS) [3]. The domains more frequently affected are processing speed, sustained and selective attention, learning and episodic memory [4,5], with executive functions compromised in more advanced, progressive stages [6]. The development of cognitive impairment mirrors the high individual variability that characterizes the manifestation of physical disability in MS and results from neurodegeneration [7], disconnection of salient regions [8] and functional reorganization, which, to a certain degree, is able to counteract the clinical manifestation of structural damage [9] contributing, together with intellectual enrichment [10], to cognitive reserve [11]. Conventional imaging can only give a glimpse into these complex underlying mechanisms, while the application of advanced neuroimaging techniques offers a more exhaustive picture of the different correlates of cognitive impairment [12-14]. In this narrative review, we provide an overview of the structural, functional and metabolic correlates of cognitive impairment in adults with MS, focusing on the more recent findings achieved via advanced neuroimaging.

\section{Structural Correlates of Cognitive Impairment \\ 2.1. White Matter Damage}

The role of white matter (WM) focal lesions as correlates of global cognitive impairment or deficit in specific cognitive functions has been widely explored in MS. Initial findings from cross-sectional studies $[15,16]$ have been confirmed by longitudinal reports 
highlighting the role of short-term lesion load changes in predicting cognitive performance at follow-up [17-19], but evidence remains contradictory [16]. Although it is not possible to directly compare studies conducted with different designs in different populations, the overall emerging message is that demyelinating lesions play a minor role in comparison with atrophy and normal appearing tissue damage [20,21]. Mechanistically, demyelinating lesions impact on cognition is related to disruption of relevant WM tracts interconnecting key grey matter (GM) regions [22]. This is true not only for nonsocial (e.g., information processing speed, memory and executive functions) cognitive domains but also for social (i.e., emotion recognition, theory of mind and empathy) cognitive domains, as highlighted by a recent review interpreting the available findings in the context of a multiple disconnection syndrome [23]. Indeed, the presence of focal lesions translates in a disruption of the brain structural network [24] and results in density reduction in lesioned tracts and impaired function [25], with damage to long-range connections impacting brain network efficiency [26]. The effects of normal appearing WM (NAWM) disruption on cognition have been confirmed by different imaging techniques, from magnetization transfer (MT) and diffusion based to quantitative MR imaging [21,27-33], exploiting their sensitivity to different pathological aspects of the disease [34]. Parameters derived from diffusion tensor imaging (DTI), such as fractional anisotropy (FA), radial diffusivity (RD) and axial diffusivity (AD), correlate with histological measures of myelination as well as with axonal density $[35,36]$. For myelin assessment, magnetization transfer ratio (MTR) and the longitudinal relaxation rate (R1) represent more direct approaches, with R1 showing the highest sensitivity in comparison with other established myelin-sensitive MRI metrics [37]. More recently, diffusion-based models such as diffusion basis spectrum imaging (DBSI) and diffusion kurtosis imaging (DKI) have been developed to characterize water diffusion properties associated with a wider range of pathological correlates [38,39] (Figure 1), with neurite orientation dispersion and density imaging (NODDI) seemingly able to capture pre-symptomatic axonal degeneration in animal models of neurodegeneration [40]. Applying DBSI and DKI, fiber density and axonal damage within NAWM have been confirmed as significant correlates of cognitive function [41,42]. Notwithstanding their limitations (i.e., modelling of crossing fibers, modelling of focal lesion effects on structural connectivity, discrimination of pathological from physiological variations in fiber orientation and dispersion) [43-45], advanced dMRI models, reflecting the intricacy of the central nervous system (CNS) microstructure, represent a valuable tool not only for the exploration of damage accrual but also neuroplastic mechanisms of functional recovery in MS [46,47].

\subsection{Gray Matter Damage}

GM lesions (both cortical and subcortical) represent an early and frequent phenomenon in MS [48], which has emerged as a specific and clinically relevant disease biomarker. This has led to the inclusion of the cortical lesion location in the diagnostic criteria [49] and to the gradual integration of dedicated MRI sequences for the in vivo assessment of cortical lesions (e.g., double-inversion recovery, DIR, phase-sensitive inversion recovery, PSIR or high-resolution 3D magnetization prepared rapid acquisition with gradient echo, MPRAGE) [50-53] into both diagnostic and follow-up imaging guidelines $[54,55]$ (Figure 2). Indeed, the number and volume of GM lesions have been consistently linked not only to physical disability, but also to cognitive impairment [56,57], independently from GM volume loss [58], adding to the sole quantification of WM lesion burden [59] and with possible region-related effects, such as the suggested association between hippocampal lesions and visuospatial memory impairment [57]. 


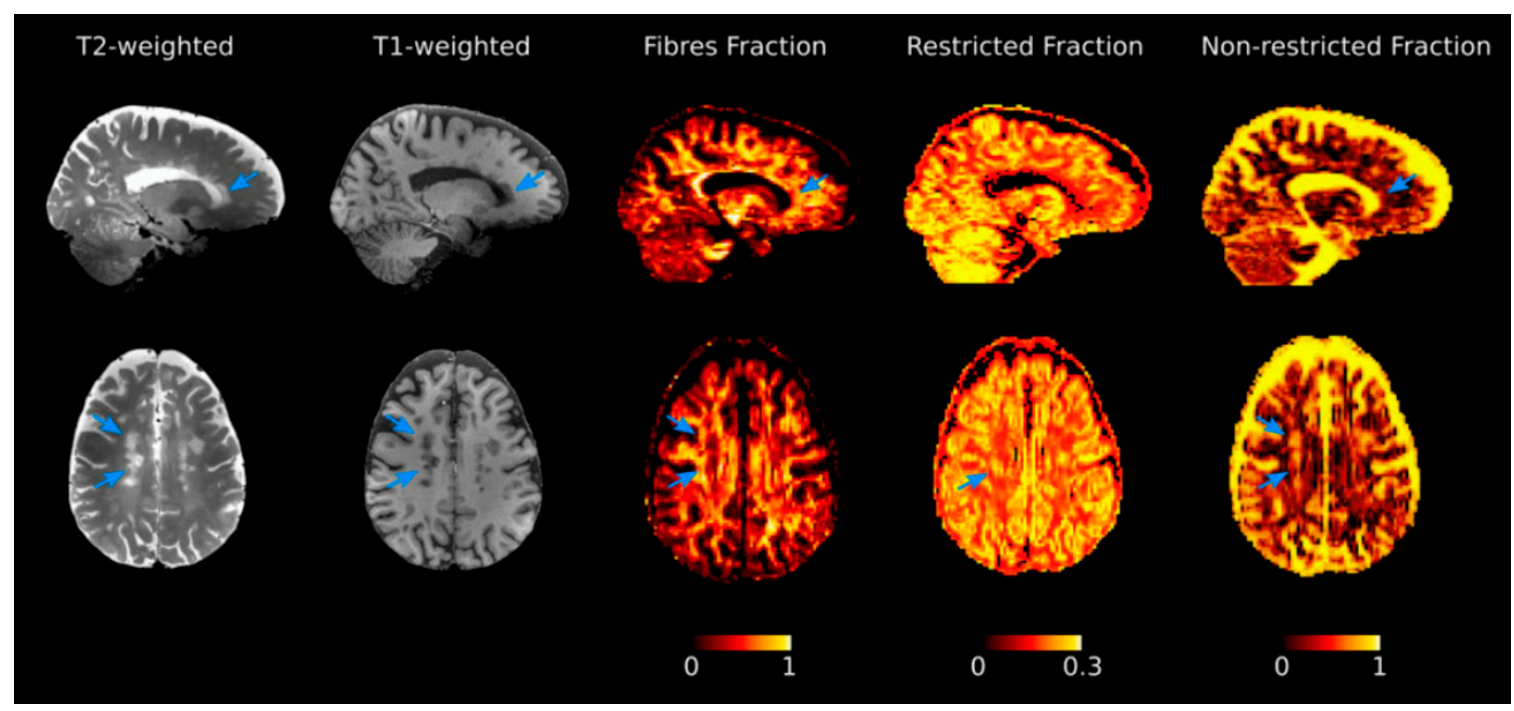

Figure 1. Diffusion basis spectrum imaging (DBSI) maps for the investigation of tissue properties. Selected T2- and T1-weighted images, together with DBSI-derived maps from a patient diagnosed with multiple sclerosis. Variations of each metric in normal appearing tissue in comparison with lesions (indicated by arrows) can be appreciated. The color bar expresses each DBSI-metric adimensional unit of measure. Reprinted from Brain, Vol. 144, Issue 1, P213-223, 12 February 2021. Schiavi S. et al. "Non-invasive quantification of inflammation, axonal and myelin injury in multiple sclerosis" [42]. Copyright: (c) 2021, with permission from Oxford University Press.

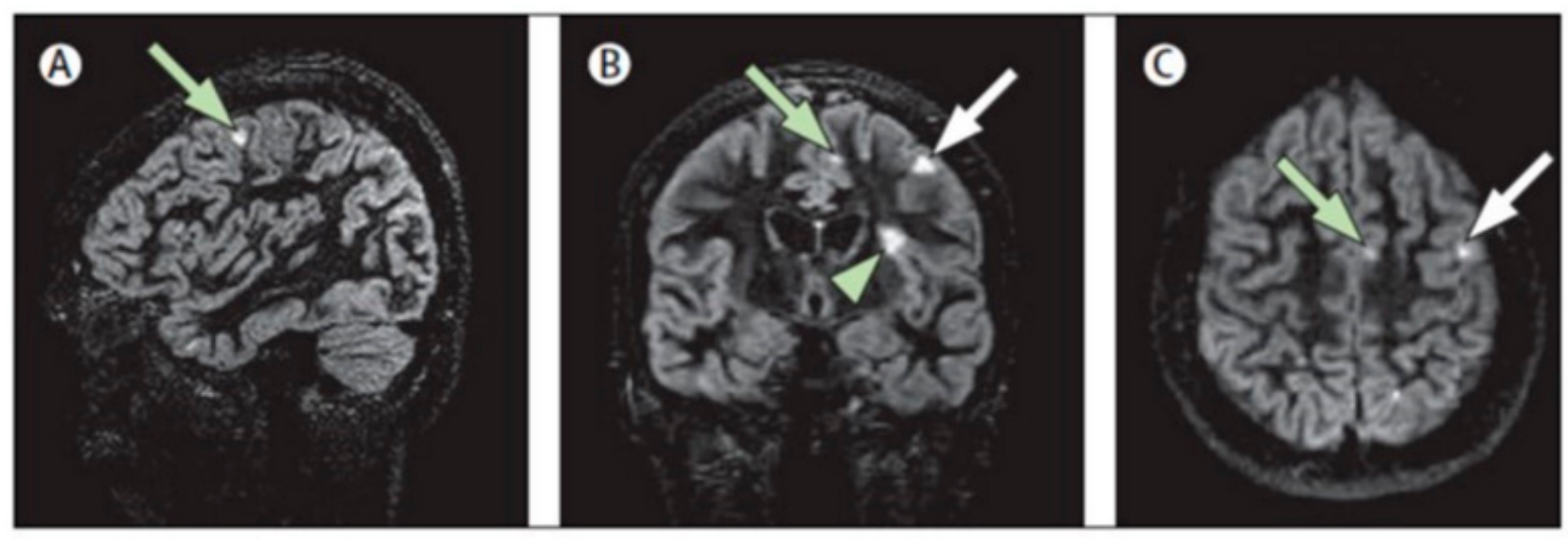

Figure 2. Multiplanar representation of single-slab 3D double-inversion recovery images of a patient with MS. (A) Sagittal view of a juxtacortical lesion (arrow) in the frontal vertex. (B) Coronal orientation: same wedge-shaped juxtacortical lesion (white arrow), as well as a mixed grey matter-white matter (type I) lesion (arrowhead) near the frontal operculum and a smaller juxtacortical lesion frontomedially (green arrow). (C) Same two juxtacortical lesions as shown in (A,B), in the axial orientation. Reprinted from The Lancet Neurology, Vol. 7, Issue 9, P841-851, 1 September 2008 [60]. Copyright: (C) 2021, with permission from Elsevier.

Besides focal GM lesions, a wide spectrum of microstructural modifications is known to occur also in the normal appearing GM (NAGM) of MS patients, going beyond (and associated with) GM atrophy [60]. The study of NAGM abnormalities in vivo, made possible by advanced MRI techniques including magnetization transfer imaging (MTI) [61], quantitative relaxometry [62], quantitative susceptibility mapping (QSM) [63] and diffusion MRI [64], has provided valuable insights into MS pathophysiology and has proved worthwhile in terms of clinical correlations, even if it is not always clear to what extent these correlations are driven by GM atrophy [60]. In particular, globally reduced MT ratio in the NAGM, considered as an index of demyelination, has been related to cognitive impairment in MS patients $[65,66]$. In accordance with this finding, T1 relaxometry studies 
demonstrated an association between cognitive impairment and higher mean values and skewness of GM T1-relaxation time, both reflecting demyelination, mainly in the thalamus and fronto-temporal cortices [67-69]. Furthermore, diffusion MRI studies, leveraging DTI [70] or alternative diffusion models [71], demonstrated that altered NAGM integrity (resulting from a combination of demyelination, axonal damage, gliosis, dendritic stripping) contributes to the explanation of cognitive deficit in MS patients, with abnormal diffusion metrics in specific GM regions associated with worse performance in distinct cognitive functions [70-72]. Finally, studies exploiting quantitative iron-sensitive MRI techniques showed mixed results, with cognitive performance negatively correlating with both magnetic susceptibility (reflecting iron content) in the globus pallidus [72] and with T2*-relaxation time (a measure inversely correlated with both iron and myelin content) in selective cortical regions [73].

\subsection{Atrophy}

Brain atrophy and cognitive impairment are both detectable from the earliest stages of MS [74,75]. Different studies have pointed to GM atrophy as a key determinant of cognitive impairment [3]. In particular, cortical GM atrophy could be involved in the development of specific attentional deficits [76], from the early stages of MS [31]. In a 5-year longitudinal study, reduced cortical GM volume at baseline was associated with the development of cognitive decline, suggesting a leading role of cortical atrophy [77].

Although simple MRI proxy of brain atrophy are useful surrogate marker of global disability [78], improvements in MRI post-processing have granted the possibility to segment different components of white and grey matter [74,79], allowing refinement of associations with cognitive features. In particular, thalamus and other deep GM structural changes play an important role in the development of the full spectrum of cognitive impairment in MS [3,31,80-82], including attention-processing speed, executive function, fluency, visuospatial working memory and verbal memory $[80,83]$. Thalamic atrophy, induced by the interplay of local and remote pathologic processes [84,85], has been associated with cognitive impairment from the early stages of MS and could further enhance cognitive changes in patients with more pronounced WM lesion load [15]. During the course of the disease, the progression of cognitive changes mirrors deep GM volume changes, suggesting a direct association [77]. Similarly, cerebellar atrophy has been associated with cognitive changes in attention-processing speed, visuo-spatial working memory and verbal memory [20]. Besides, hippocampal atrophy looks more specifically related to visuo-spatial working memory and verbal memory deficits [32].

In conclusion, structural changes in the GM have been associated with cognitive impairment in MS, with the involvement of multiple neuropsychological domains and brain areas, including the thalamus, cerebellum and hippocampus.

\subsection{Network Modifications}

In recent years, looking at the brain as a complex system consisting of many neural elements whose interconnection at different scales of space and time underlies clinicalcognitive functioning, pathophysiological models of brain disorders have shifted from an emphasis on characterizing pathology in specific regions to understanding disturbances at the level of networks, defined by connections and their topology [86].

MRI provides the means to assess the macro-scale architecture of brain connectivity, characterized as the anatomical links between different GM regions estimated with diffusion MRI tractography, by the similarity in GM morphological features (i.e., cortical thickness) derived from structural MRI or by the statistical dependence of GM regions' signal time courses in functional MRI [87]. While network-based analyses conducted so far offered mixed results, which are not easily interpretable in the light of clinical outcomes, a number of diffusion MRI studies seem to point towards a reduction in topological efficiency (a measure of network integration) in MS patients' structural connectome [88,89], which is best explained by the disruption of long-range WM tracts [26] and the disconnec- 
tion of main hubs such as the thalamus and nodes of the default-mode network (DMN) [90], and underlies cognitive dysfunction [91,92] (Figure 3).

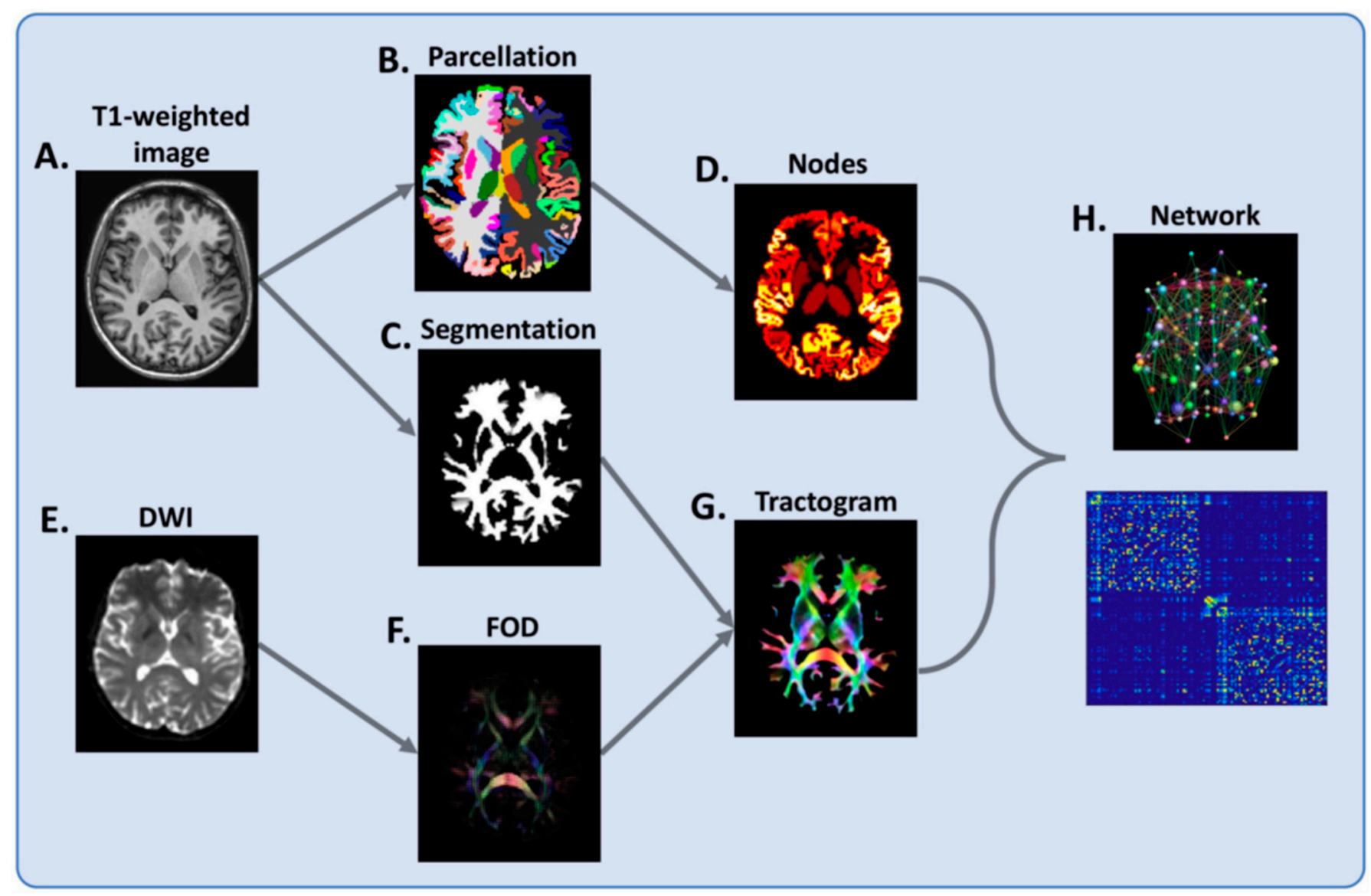

Figure 3. Flowchart of brain network reconstruction. For each subject, (A) T1-weighted image is segmented into grey matter (B) and white matter $(\mathbf{C})$. The grey matter segmentation is parcellated into cortical and deep grey matter regions (B), which serve as network nodes (D) in the subsequent network-based analysis. From a diffusion-weighted image (DWI) (E), voxel-wise fiber orientation distribution (FOD) (F) is estimated and whole-brain tractography undertaken (G), with the white matter segmentation (C) used to prevent this from spilling into grey matter. Finally, nodes and tractogram are modelled into a network $(\mathbf{H})$. Connections are weighted by the sum of the pairwise streamline weights. Reprinted from JNNP, Vol. 90, Issue 2, 01 February 2019 [91]. Copyright: (C) 2021, with permission from BMJ Publishing Group Ltd.

Accordingly, MS has been described as a disconnection syndrome, with "network collapse" suggested as a putative mechanism through which cumulative structural brain pathology ultimately leads to clinical-cognitive disability [9,93].

Furthermore, studies exploring the patterns of anatomical covariance between GM regions demonstrated not only that GM atrophy in MS patients occurs according to distinct spatial patterns, which partially explains the variability of cognitive outcomes [94], but also that structural damage in MS tends to disrupt the coordinated patterns of morphological homology between GM regions, leading to a more random GM network organization, which correlates with worse cognitive functioning independently of GM atrophy $[95,96]$.

\section{Functional and Metabolic Correlates}

\subsection{Functional MRI}

Functional MRI (fMRI) is an advanced imaging technique based on the detection and evaluation of blood oxygen level-dependent (BOLD) changes that occurs during neuronal activity. Indeed, neuronal activation leads to an increase in metabolic requirements from brain parenchyma, which is achieved by increasing the arterial blood flow. Nevertheless, 
this increase is not coupled to a similar capillary extraction of oxygen, which leads, therefore, to a relative decrease in deoxyhemoglobin concentrations that is possible to detect via MRI as an index of neuronal activity [97].

With a great effort of synthesis, fMRI studies can be divided in task and rest-related experiments. While task fMRI studies measure BOLD changes after an active execution of any performance (e.g., a motor task, a verbal fluency test, etc.), the latter approach evaluates the interactions occurring between different brain regions without the execution of any specific task and, for this reason, goes under the name of resting-state fMRI (RS-fMRI). This approach allows for the demonstration of the presence of preferential functional connectivity (FC) between cerebral structures, which results in organized and stable and reliable networks [97].

Although in the past years several studies have investigated possible changes in cerebral functions by means of task-related fMRI experiments in MS patients [98-103], a great contribution to our understanding of functional brain damage in MS, with particular reference to cognition, comes from RS-fMRI studies. Among all the networks that have been studied in MS, a central role has emerged for DMN modifications. Indeed, FC changes affecting some of the nodes of this network have been reported in MS, both in terms of an increased [104] and a decreased [105,106] FC, as well as changes in local regional homogeneity [107] and variability [108].

In particular, an increased FC of the posterior cingulate gyrus has been reported in clinically isolated syndrome, which appears to be lost in relapsing-remitting patients [104]. On the other hand, a decrease in the FC of the anterior cingulate cortex, which is an anterior hub of the DMN, has been found in relapsing-remitting patients and, in particular, in patients showing a relatively preserved cognitive function [105]. These results suggest that cognitive impairment might contribute in a different way to MS-related DMN changes in relapsing-remitting MS, at least at the level of this anterior hub of the DMN [105]. To further support this finding, a reduction in the anterior cingulate cortex FC was also found when primary-progressive patients where compared to subjects with secondary-progressive MS, with activity reduction more pronounced in patients with cognitive impairment, therefore suggesting the possible involvement of this area as one of the factor causing the accrual of cognitive deficits in progressive MS patients [106]. It is noteworthy to mention that FC changes have been identified not only in supratentorial areas, but also the infratentorial compartment. In particular, cerebellar FC changes have been reported in pediatric [109], relapsing-remitting [110] and progressive MS [111] patients, showing some degree of correlation with cognitive scores, further supporting the role of cerebellum in cognition [20,112-116] (Figure 4). As per the nature of the reported FC changes, they seem to play a compensatory role to structural damage in the early disease stages, until damage accrual determines a network collapse leading to manifest cognitive deficit [9]. Again, this holds true also for the less explored social cognition domains, where fMRI studies [117,118] showed regional hyperactivation in individuals without social cognition deficits, providing evidence of adaptative functional reorganization, with hypoactivation on $\mathrm{fMRI}$ and/or social cognition deficits [119] identifiable only at later disease stages.

\subsection{Positron Emission Tomography}

Positron emission tomography (PET) is a quantitative non-invasive imaging technique that allows to measures in vivo the distribution of an exogenous radionuclide targeting specific cellular molecules. Therefore, it is well placed to study biological substrates underpinning MS pathology. So far, three pathological processes occurring in MS have been explored through PET: inflammation, demyelination/remyelination and axonal degeneration (Figure 5). 


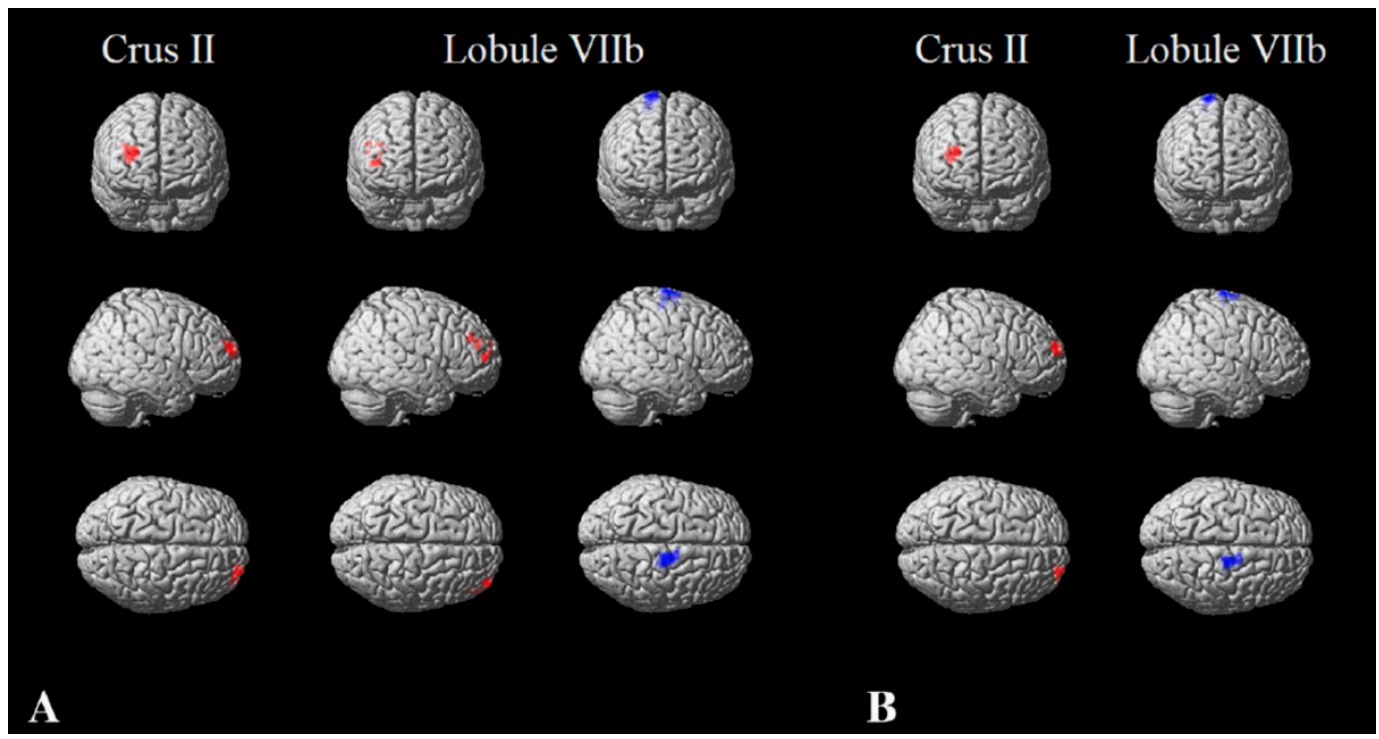

Figure 4. Cerebellar functional connectivity in multiple sclerosis. Cerebellar functional connectivity modification in patients with multiple sclerosis compared to controls, without taking into account (A) and after controlling (B) for cerebellar structural damage. Clusters of significant functional connectivity decrease are shown in red, while clusters of significant functional connectivity increase are presented in blue, superimposed on a standard 3D rendering of a brain volume in the Montreal Neurological Institute space. Reprinted from JOON, Vol. 265, Issue 10, P2260-2266, October 2018 [111]. Copyright: (C) 2021, with permission from Springer Nature.

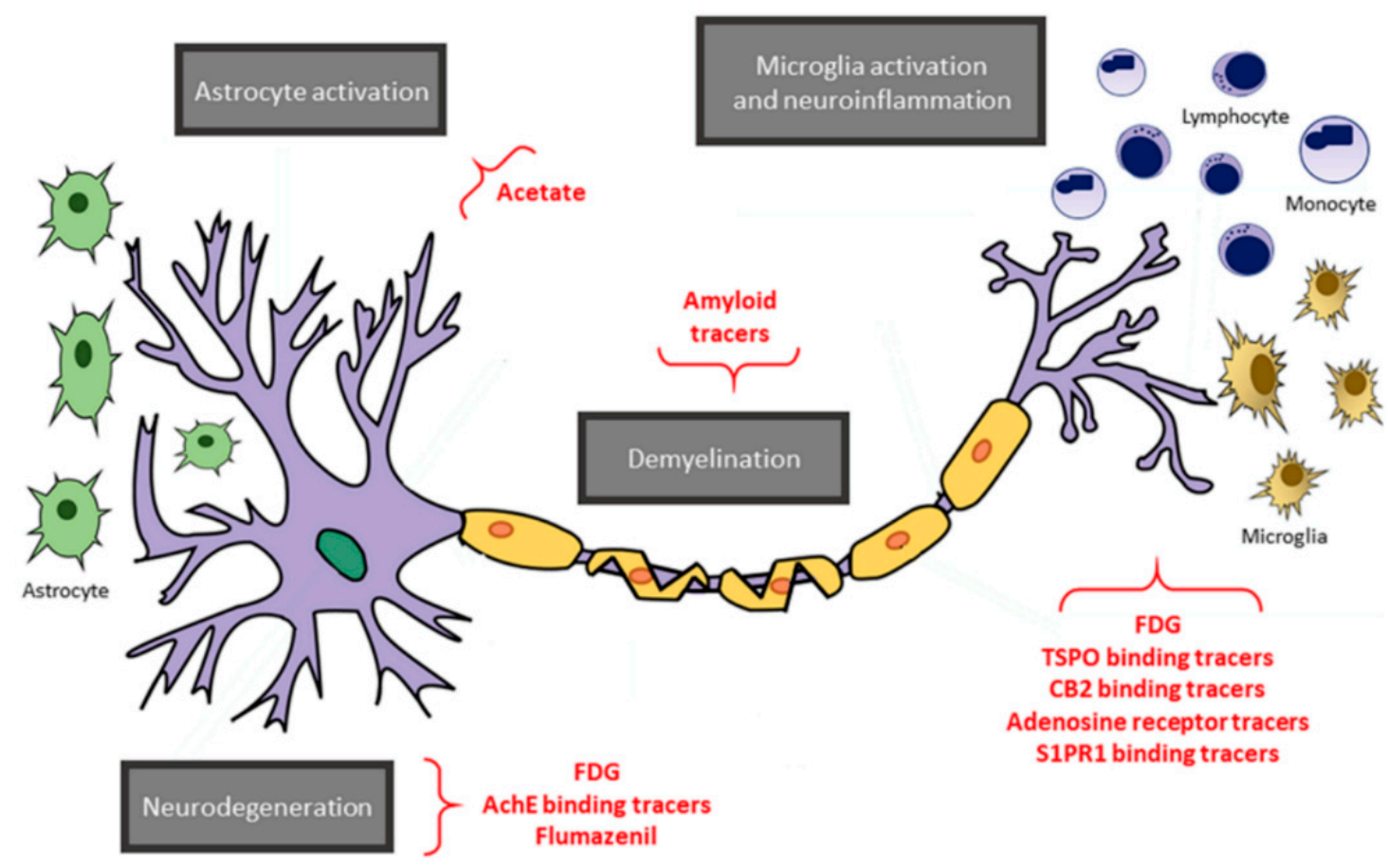

Figure 5. An overview of positron emission tomography (PET) targets and tracers. A schematic representation of the main targets of PET imaging in multiple sclerosis (gray boxes), along with the respective tracers (in red). Reprinted from EJNMMI Radiopharmacy and Chemistry Vol. 4, Issue 1, P6, 8 April 2019 [120]. Copyright: @ 2021, with permission from Springer Open.

Inflammation was mostly evaluated by measuring microglia activation targeting the peripheral benzodiazepine receptor (PBR), also known as TSPO. To date, TSPO-binding $\left[{ }^{11} \mathrm{C}\right] \mathrm{PK} 11195$ ligand has been widely used in MS. [ $\left.{ }^{11} \mathrm{C}\right] \mathrm{PK} 11195$ PET studies have shown an increased tracer distribution in the NAWM, T2-, T1- and Gadolinium-enhanced cortical 
and subcortical GM in MS patients compared with healthy controls [121-126]. Interestingly, at the very early stages of the disease, patients already display an increased extent of microglia activation throughout NAWM, which predicts disease course over the followup $[127,128]$. Additionally, it has been demonstrated that increased neuroinflammation in the thalamus is linked with cortical atrophy [129]. In the same study, authors associated cognitive impairment with neuroinflammation in the cortex, deep GM and NAWM [129]. Since both cortical atrophy and a widespread inflammatory status were already associated with cognitive impairment, of great interest would be the investigation of the temporal dynamic linking atrophy, inflammation and cognitive impairment, in order to disentangle the contribution of neurodegeneration and neuroinflammation to cognition $[30,56,130]$.

Neurodegeneration could also be assessed in MS through PET imaging by measuring either GABAA receptors, through $\left[{ }^{18} \mathrm{~F}\right]$ flumazenil or two-deoxy-2-[fluorine-18]fluoro-Dglucose $\left(\left[{ }^{18} \mathrm{~F}\right] \mathrm{FDG}\right)$ (Figure 5$)$. The latter measures the metabolic rate of glucose utilization (CMRglu), and hence, it is a marker of presynaptic neuronal function [130]. Using $\left[{ }^{18} \mathrm{~F}\right]$ flumazenil PET imaging, Freeman et al. demonstrated that MS patients show an overall decreased tracer binding in the GM, which was associated with cognitive impairment [131]. Notably, such decreased $\left[{ }^{18} \mathrm{~F}\right]$ flumazenil uptake was not associated with atrophy detected through conventional MRI imaging. Therefore, $\left[{ }^{18} \mathrm{~F}\right]$ flumazenil PET imaging seems to be able to detect GM pathology even before MRI markers of neurodegeneration are evident. Similarly, PET imaging studies using $\left[{ }^{18} \mathrm{~F}\right]$ FDG showed that MS patients have a reduced CMRglu in the GM, which worsens over the disease course [132]. Hypometabolism in deep GM is associated with cognitive impairment especially in thalamus [133], outlining the central role of this structure in cognitive function. However, despite these findings, $\left[{ }^{18} \mathrm{~F}\right]$ FDG lacks specificity, and its application in MS is limited due to high background binding within the brain.

Finally, also, demyelination/remyelination assessment in MS has received growing interest. Lesion load as well as lesion location and the extent of tissue damage within demyelinating lesions are strongly associated with cognitive impairment and could also predict cognitive worsening overtime [30]. First used tracers for myelin were amyloid- $\beta$ protein targeting ligands (Figure 5). These stilbenes and benzothiazole derivatives have a very flat structure, interacting with the secondary structure of myelin basic protein similarly to the way they interact with amyloid $[134,135]$. Actually, myelin basic protein has a particular two-dimensional secondary structure, acting as a hinge between lipid bilayers. In this structure, stilbene and benzothiazole derivatives are trapped, and hence, when lipid bilayers are damaged, a lower uptake is detectable. The most used tracers to assess myelination are the Carbon-11-labeled Pittsburgh compound B $\left(\left[{ }^{11} \mathrm{C}\right] \mathrm{PIB}\right),\left[{ }^{18} \mathrm{~F}\right]$ florbetaben and $\left[{ }^{18} \mathrm{~F}\right]$ florbetapir $[136,137]$. To date, only ${ }^{18} \mathrm{~F}$-Florbetaben uptake was associated to the extent of cognitive impairment [138]. Therefore, further studies integrating MRI structural analysis and PET data are highly needed in order to understand whether PET may reveal myelin damage beyond what can be detected through standard MRI, thus contributing to the exploration of cognitive dysfunction in MS. Amyloid PET imaging might also be used to differentiate MS-related cognitive decline from other neurodegenerative diseases associated with amyloid deposition such as Alzheimer's disease. To date, no studies have been performed to explore this possibility. As matter of fact, while amyloid deposition for Alzheimer's disease occurs throughout GM, and hence, analyses focus on this compartment, amyloid PET imaging in MS does not measure amyloid deposition, as it focuses on WM compartment, and the binding is not specific as for amyloid protein. A multi-parametric study demonstrated the association between Florbetapir PET uptake in NAWM and cerebrospinal fluid $\beta$-amyloid [139]. However, in this case, $\beta$-amyloid reflected the extent of neuronal damages and not protein accumulation. A study performing a between-group comparison using healthy volunteers, MS patients with and without cognitive impairment and patients with $\beta$-amyloid accumulation-related neurodegenerative diseases may shed light on the possible role of amyloid PET imaging as tool to solve differential diagnosis issues. 
In conclusion, despite its promising results and potential applications, clinical application of PET imaging is still hampered by the high costs, the need for skilled operators both for data acquisition and analysis, the low PET resolution and the need for development of specific tracers. However, the introduction of hybrid PET/MRI scans may be useful to reduce costs and acquisition time, allowing the simultaneous acquisition of PET and MRI imaging with the advantage of evaluating with a higher extent of specificity biological processes associated with MS pathology.

\subsection{Magnetic Resonance Spectroscopy}

Magnetic resonance spectroscopy (MRS) is an imaging technique allowing the measurement of metabolites in the brain when these are present in relatively high concentrations. Differently from MRI, mainly relying on proton $\left({ }^{1} \mathrm{H}\right)$, MRS can rely on a variety of nuclei. However, ${ }^{1} \mathrm{H}-\mathrm{MRS}$ is the most used methodology when it turns to neurological disorders, as it allows us to evaluate a large number of molecules such as the N-acetylaspartate (NAA), glutamate (Glu) and glutamine (Gln), choline (Cho), creatine (Cr) and myoinositol (mI). Each of this molecule reflects ongoing pathological processes.

NAA is an amino acid derivative synthesized in neurons and transported down over the axons. It is considered a specific marker of neurons, axons and dendrites integrity $[140,141]$. In MS, NAA can be measured either as absolute value or normalized for intra-voxel Cr concentration (NAA/Cr). NAA levels were shown to be lower in acute lesion with concentrations only partly recovering over the follow-up, being lower than healthy controls' WM [142,143]. Similarly, NAA concentration also progressively reduces in NAWM from the very early stages, with the lowest concentrations observed in progressive phenotypes [144,145]. Data concerning NAA concentration in GM are still conflicting and deserve to be further investigated. All in all, NAA may be considered as a marker of axonal loss and/or metabolic dysfunction. NAA concentration in NAWM, and not in GM, has been associated with attention functioning in MS [146]. As NAA levels are markers of axonal loss, one may argue that a closer association between cognition and NAA levels would have been expected in GM rather than in NAWM. Perhaps, it could be hypothesized that axonal transection due to demyelination over WM fiber bundles revealed by NAA levels may precede axonal loss occurring in GM. Longitudinal analyses may shed further light on this topic.

Differently from NAA, Glu and Gln are considered as markers of inflammation, and increased Glu and Gln levels are associated with neurotoxicity, as they are excitatory neurotransmitters [147]. In MS, a widespread increase in Glu and Gln levels has been observed in WM lesions, NAWM and GM both in the relapsing and progressive phenotypes [148-151]. Interestingly, Glu levels in NAWM are also associated to brain atrophy, disability accrual and cognitive impairment $[147,149]$, thus mirroring results obtained through TSPO PET imaging [129]. While Glu is an excitatory neurotransmitter, gamma-aminobutyric acid (GABA) is the major inhibitory neurotransmitter in the brain. The assessment of GABA levels in MS is still debated. Available findings suggest that a reduction in GABA in GM is associated with motor function in MS [152]. Interestingly, such a reduction might be related over time to a reactive increase in functional connectivity that can minimize clinical worsening [153]. To date no association has been reported between GABA levels and cognition.

Cho signal reflects cell membrane metabolism and elevated Cho concentrations represent a high cell membrane turnover manifesting during demyelination, re-myelination, inflammation and gliosis in MS patients [154]. Several studies reported increased Cho levels in NAWM of relapsing MS patients and such an increase seems to precede the appearance of gadolinium enhancing lesions $[143,155]$. However, in progressive MS patients, data are still conflicting, and no conclusion can be drawn $[155,156]$. Cho in cortical GM was associated with the PASAT3, a cognitive test assessing sustained attention [146]. Therefore, although axonal transection over fiber bundles may occur and underpins cognitive impairment, also a higher membrane turn-over likely contributes to this dysfunction, probably mirroring ongoing damages in the axonal soma. 
$\mathrm{Cr}$ and $\mathrm{mI}$ levels were shown to be associated to both energy metabolism and gliosis [140]. Overall, $\mathrm{Cr}$ and mI levels increased in WM lesions, NAWM and GM in MS patients compared with healthy controls [152,157,158].

In conclusion, MRS is a promising technique that allows the quantification of metabolites concentrations reflecting MS pathological processes. Nevertheless, it has technical limitations, such as the very low spatial resolution and high spectra sensitivity to variations in B0 and B1 magnetic fields, that still need to be addressed before clinical application can be implemented.

\subsection{Sodium MRI}

Sodium imaging allows the estimation of brain total sodium concentration (TSC), which reflects intra- and extracellular sodium concentration [157] (Figure 6). TSC increase in MS, related to neuro-axonal metabolic dysfunction [158] and/or expansion of the extracellular space secondary to neuro-axonal loss or edema $[159,160]$, has been reported by several independent groups [157,161-166]. Recently, TSC increase in the cortex of MS patients has shown an independent and better association with cognitive impairment than GM atrophy $[161,164]$. Although this might suggest a role for TSC as marker of neuronal dysfunction rather than an indirect measure of cellular loss, future studies exploring selectively the relation between cognition and intracellular sodium concentration, which more closely captures changes in cellular metabolism related to mitochondrial and ion channels dysfunction [157], are warranted to confirm this hypothesis.

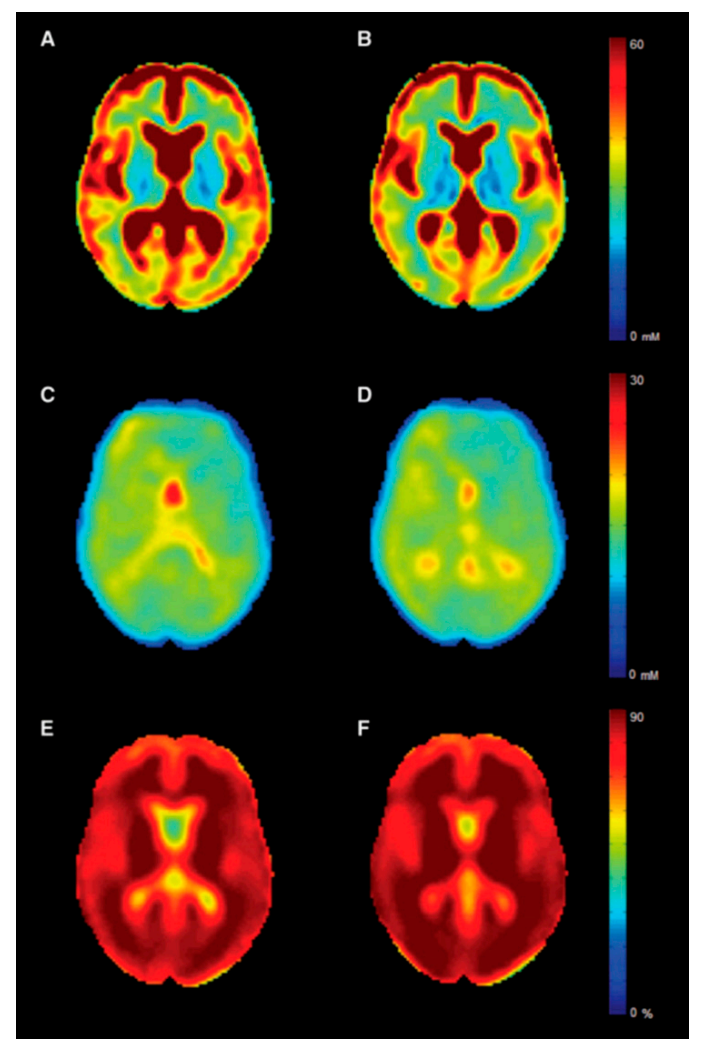

Figure 6. Sodium maps. Mean sodium MRI maps for multiple sclerosis patients (left column) and controls (right column). In the first row is displayed the total sodium concentration (A,B), while in the middle and last rows, the intracellular sodium concentration $(\mathbf{C}, \mathbf{D})$ and the intracellular sodium volume fraction (indirect measure of extracellular sodium concentration) (E,F) are shown. Reprinted from Brain, Vol. 139, Issue 3, P 795-806, 20 January 2016 [167]. Copyright: (c 2021] with permission from Oxford University Press. 


\title{
4. Conclusions
}

Over recent years, the development of new MRI sequences and modelling approaches has allowed the characterization of many structural and functional correlates of cognitive impairment in MS, providing new tools for disease monitoring and identifying new potential therapeutic targets. Although many questions remain unanswered, the value of advanced neuroimaging as an investigative tool of pathological changes in vivo remains undisputed, and future developments in this field will steadily add to our understanding of cognitive involvement in MS.

Author Contributions: Conceptualization, M.P., R.L., V.B.M.; resources, V.B.M.; writing—original draft preparation, all authors; writing - review and editing, all authors. All authors have read and agreed to the published version of the manuscript.

Funding: This research received no external funding.

Conflicts of Interest: The authors declare no conflict of interest.

\begin{abstract}
Abbreviations
$\left[{ }^{11} \mathrm{C}\right] \mathrm{PIB}=$ carbon-11-labeled Pittsburgh compound B; $\left[{ }^{18} \mathrm{~F}\right] \mathrm{FDG}=$ two-deoxy-2-[fluorine-18]fluoro-Dglucose; $\mathrm{AD}=$ axial diffusivity; $\mathrm{BOLD}=$ blood oxygen level-dependent; $\mathrm{Cho}=$ choline; $\mathrm{CNS}=$ central nervous system; $\mathrm{CMRglu}=$ metabolic rate of glucose utilization; $\mathrm{Cr}=$ creatine; $\mathrm{DBSI}=$ diffusion basis spectrum imaging; $\mathrm{DIR}=$ double-inversion recovery; $\mathrm{DMN}=$ default-mode network; $\mathrm{DKI}=$ diffusion kurtosis imaging; $\mathrm{DTI}=$ diffusion tensor imaging; $\mathrm{FA}=$ fractional anisotropy; $\mathrm{FC}=$ functional connectivity; fMRI = functional MRI; GABA = gamma-aminobutyric acid; Glu = glutamate; $\mathrm{Gln}$ = glutamine; $\mathrm{GM}=$ grey matter; $\mathrm{mI}=$ myoinositol; $\mathrm{MPRAGE}=$ magnetization prepared rapid acquisition with gradient echo; MRS = magnetic resonance spectroscopy; MS = multiple sclerosis; MT = magnetization transfer; MTI = magnetization transfer imaging; MTR = magnetization transfer ratio; NAA $=\mathrm{N}$-acetylaspartate; NAGM = normal appearing grey matter; NAWM = normal appearing white matter; NODDI = neurite orientation dispersion and density imaging; $\mathrm{PBR}=$ peripheral benzodiazepine receptor PET = positron emission tomography; PSIR = phase-sensitive inversion recovery; $\mathrm{QSM}=$ quantitative susceptibility mapping; $\mathrm{R} 1$ = longitudinal relaxation rate; $\mathrm{RD}=$ radial diffusivity; RS-fMRI = Resting-State $\mathrm{fMRI} ; \mathrm{TSC}=$ total sodium concentration; $\mathrm{WM}=$ white matter.
\end{abstract}

\section{References}

1. Amato, M.P.; Hakiki, B.; Goretti, B.; Rossi, F.; Stromillo, M.L.; Giorgio, A.; Roscio, M.; Ghezzi, A.; Guidi, L.; Bartolozzi, M.L.; et al. Association of MRI metrics and cognitive impairment in radiologically isolated syndromes. Neurology 2012, 78, 309-314. [CrossRef]

2. Uher, T.; Blahova-Dusankova, J.; Horakova, D.; Bergsland, N.; Tyblova, M.; Benedict, R.H.; Kalincik, T.; Ramasamy, D.P.; Seidl, Z.; Hagermeier, J.; et al. Longitudinal MRI and neuropsychological assessment of patients with clinically isolated syndrome. J. Neurol. 2014, 261, 1735-1744. [CrossRef]

3. Benedict, R.H.B.; Amato, M.P.; DeLuca, J.; Geurts, J.J.G. Cognitive impairment in multiple sclerosis: Clinical management, MRI, and therapeutic avenues. Lancet Neurol. 2020, 19, 860-871. [CrossRef]

4. Benedict, R.H.; Cookfair, D.; Gavett, R.; Gunther, M.; Munschauer, F.; Garg, N.; Weinstock-Guttman, B. Validity of the minimal assessment of cognitive function in multiple sclerosis (MACFIMS). J. Int. Neuropsychol. Soc. JINS 2006, 12, 549-558. [CrossRef] [PubMed]

5. Rao, S.M.; Leo, G.J.; Bernardin, L.; Unverzagt, F. Cognitive dysfunction in multiple sclerosis. I. Frequency, patterns, and prediction. Neurology 1991, 41, 685-691. [CrossRef] [PubMed]

6. Branco, M.; Ruano, L.; Portaccio, E.; Goretti, B.; Niccolai, C.; Patti, F.; Chisari, C.; Gallo, P.; Grossi, P.; Ghezzi, A.; et al. Aging with multiple sclerosis: Prevalence and profile of cognitive impairment. Neurol. Sci. Off. J. Ital. Neurol. Soc. Ital. Soc. Clin. Neurophysiol. 2019, 40, 1651-1657. [CrossRef]

7. Geurts, J.J.; Calabrese, M.; Fisher, E.; Rudick, R.A. Measurement and clinical effect of grey matter pathology in multiple sclerosis. Lancet Neurol. 2012, 11, 1082-1092. [CrossRef]

8. Dineen, R.A.; Vilisaar, J.; Hlinka, J.; Bradshaw, C.M.; Morgan, P.S.; Constantinescu, C.S.; Auer, D.P. Disconnection as a mechanism for cognitive dysfunction in multiple sclerosis. Brain J. Neurol. 2009, 132 Pt 1, 239-249. [CrossRef]

9. Schoonheim, M.M.; Meijer, K.A.; Geurts, J.J. Network collapse and cognitive impairment in multiple sclerosis. Front. Neurol. 2015, 6, 82. [CrossRef] 
10. Sumowski, J.F.; Wylie, G.R.; Deluca, J.; Chiaravalloti, N. Intellectual enrichment is linked to cerebral efficiency in multiple sclerosis: Functional magnetic resonance imaging evidence for cognitive reserve. Brain J. Neurol. 2010, 133 Pt 2, 362-374. [CrossRef]

11. Fuchs, T.A.; Benedict, R.H.B.; Bartnik, A.; Choudhery, S.; Li, X.; Mallory, M.; Oship, D.; Yasin, F.; Ashton, K.; Jakimovski, D.; et al. Preserved network functional connectivity underlies cognitive reserve in multiple sclerosis. Hum. Brain Mapp. 2019, 40, 5231-5241. [CrossRef]

12. Bagnato, F.; Gauthier, S.A.; Laule, C.; Moore, G.R.W.; Bove, R.; Cai, Z.; Cohen-Adad, J.; Harrison, D.M.; Klawiter, E.C.; Morrow, S.A.; et al. Imaging mechanisms of disease progression in multiple sclerosis: Beyond brain atrophy. J. Neuroimaging Off. J. Am. Soc. Neuroimaging 2020, 30, 251-266. [CrossRef]

13. Bester, M.; Petracca, M.; Inglese, M. Neuroimaging of multiple sclerosis, acute disseminated encephalomyelitis, and other demyelinating diseases. Semin. Roentgenol. 2014, 49, 76-85. [CrossRef] [PubMed]

14. Inglese, M.; Petracca, M. MRI in multiple sclerosis: Clinical and research update. Curr. Opin. Neurol. 2018, 31, 249-255. [CrossRef]

15. Engl, C.; Tiemann, L.; Grahl, S.; Bussas, M.; Schmidt, P.; Pongratz, V.; Berthele, A.; Beer, A.; Gaser, C.; Kirschke, J.S.; et al. Cognitive impairment in early MS: Contribution of white matter lesions, deep grey matter atrophy, and cortical atrophy. J. Neurol. 2020, 267, 2307-2318. [CrossRef] [PubMed]

16. Rocca, M.A.; Amato, M.P.; De Stefano, N.; Enzinger, C.; Geurts, J.J.; Penner, I.K.; Rovira, A.; Sumowski, J.F.; Valsasina, P.; Filippi, M. Clinical and imaging assessment of cognitive dysfunction in multiple sclerosis. Lancet Neurol. 2015, 14, 302-317. [CrossRef]

17. Camp, S.J.; Stevenson, V.L.; Thompson, A.J.; Ingle, G.T.; Miller, D.H.; Borras, C.; Brochet, B.; Dousset, V.; Falautano, M.; Filippi, M.; et al. A longitudinal study of cognition in primary progressive multiple sclerosis. Brain J. Neurol. 2005, 128 Pt 12, 2891-2898. [CrossRef]

18. Hohol, M.J.; Guttmann, C.R.; Orav, J.; Mackin, G.A.; Kikinis, R.; Khoury, S.J.; Jolesz, F.A.; Weiner, H.L. Serial neuropsychological assessment and magnetic resonance imaging analysis in multiple sclerosis. Arch. Neurol. 1997, 54, 1018-1025. [CrossRef]

19. Wybrecht, D.; Reuter, F.; Zaaraoui, W.; Faivre, A.; Crespy, L.; Rico, A.; Malikova, I.; Confort-Gouny, S.; Soulier, E.; Cozzone, P.J.; et al. Voxelwise analysis of conventional magnetic resonance imaging to predict future disability in early relapsing-remitting multiple sclerosis. Mult. Scler. J. 2012, 18, 1585-1591. [CrossRef] [PubMed]

20. Cocozza, S.; Petracca, M.; Mormina, E.; Buyukturkoglu, K.; Podranski, K.; Heinig, M.M.; Pontillo, G.; Russo, C.; Tedeschi, E.; Russo, C.V.; et al. Cerebellar lobule atrophy and disability in progressive MS. J. Neurol. Neurosurg. Psychiatry 2017, 88, 1065-1072. [CrossRef]

21. Daams, M.; Steenwijk, M.D.; Schoonheim, M.M.; Wattjes, M.P.; Balk, L.J.; Tewarie, P.K.; Killestein, J.; Uitdehaag, B.M.; Geurts, J.J.; Barkhof, F. Multi-parametric structural magnetic resonance imaging in relation to cognitive dysfunction in long-standing multiple sclerosis. Mult. Scler. J. 2016, 22, 608-619. [CrossRef]

22. Rossi, F.; Giorgio, A.; Battaglini, M.; Stromillo, M.L.; Portaccio, E.; Goretti, B.; Federico, A.; Hakiki, B.; Amato, M.P.; De Stefano, N. Relevance of brain lesion location to cognition in relapsing multiple sclerosis. PLoS ONE 2012, 7, e44826. [CrossRef]

23. Chalah, M.A.; Ayache, S.S. A scope of the social brain in multiple sclerosis: Insights from neuroimaging studies. Cogn. Behav. Neurol. Off. J. Soc. Behav. Cogn. Neurol. 2020, 33, 90-102. [CrossRef]

24. Schiavi, S.; Petracca, M.; Battocchio, M.; El Mendili, M.M.; Paduri, S.; Fleysher, L.; Inglese, M.; Daducci, A. Sensory-motor network topology in multiple sclerosis: Structural connectivity analysis accounting for intrinsic density discrepancy. Hum. Brain Mapp. 2020, 41, 2951-2963. [CrossRef]

25. Petracca, M.; Schiavi, S.; Battocchio, M.; El Mendili, M.M.; Fleysher, L.; Daducci, A.; Inglese, M. Streamline density and lesion volume reveal a postero-anterior gradient of corpus callosum damage in multiple sclerosis. Eur. J. Neurol. 2020, 27, 1076-1082. [CrossRef]

26. Meijer, K.A.; Steenwijk, M.D.; Douw, L.; Schoonheim, M.M.; Geurts, J.J.G. Long-range connections are more severely damaged and relevant for cognition in multiple sclerosis. Brain J. Neurol. 2020, 143, 150-160. [CrossRef] [PubMed]

27. Bonnier, G.; Roche, A.; Romascano, D.; Simioni, S.; Meskaldji, D.; Rotzinger, D.; Lin, Y.C.; Menegaz, G.; Schluep, M.; Du Pasquier, R.; et al. Advanced MRI unravels the nature of tissue alterations in early multiple sclerosis. Ann. Clin. Transl. Neurol. 2014, 1, 423-432. [CrossRef] [PubMed]

28. Deloire, M.S.; Ruet, A.; Hamel, D.; Bonnet, M.; Dousset, V.; Brochet, B. MRI predictors of cognitive outcome in early multiple sclerosis. Neurology 2011, 76, 1161-1167. [CrossRef] [PubMed]

29. Pinter, D.; Khalil, M.; Pichler, A.; Langkammer, C.; Ropele, S.; Marschik, P.B.; Fuchs, S.; Fazekas, F.; Enzinger, C. Predictive value of different conventional and non-conventional MRI-parameters for specific domains of cognitive function in multiple sclerosis. Neuroimage Clin. 2015, 7, 715-720. [CrossRef]

30. Preziosa, P.; Rocca, M.A.; Pagani, E.; Stromillo, M.L.; Enzinger, C.; Gallo, A.; Hulst, H.E.; Atzori, M.; Pareto, D.; Riccitelli, G.C.; et al. Structural MRI correlates of cognitive impairment in patients with multiple sclerosis: A Multicenter Study. Hum. Brain Mapp. 2016, 37, 1627-1644. [CrossRef] [PubMed]

31. Riccitelli, G.C.; Pagani, E.; Meani, A.; Valsasina, P.; Preziosa, P.; Filippi, M.; Rocca, M.A. Cognitive impairment in benign multiple sclerosis: A multiparametric structural and functional MRI study. J. Neurol. 2020, 267, 3508-3517. [CrossRef] [PubMed]

32. Tóth, E.; Faragó, P.; Király, A.; Szabó, N.; Veréb, D.; Kocsis, K.; Kincses, B.; Sandi, D.; Bencsik, K.; Vécsei, L.; et al. The contribution of various MRI parameters to clinical and cognitive disability in multiple sclerosis. Front. Neurol. 2018, 9, 1172. [CrossRef] [PubMed] 
33. Mustafi, S.M.; Harezlak, J.; Kodiweera, C.; Randolph, J.S.; Ford, J.C.; Wishart, H.A.; Wu, Y.C. Detecting white matter alterations in multiple sclerosis using advanced diffusion magnetic resonance imaging. Neural Regen. Res. 2019, 14, 114-123. [CrossRef] [PubMed]

34. Lipp, I.; Jones, D.K.; Bells, S.; Sgarlata, E.; Foster, C.; Stickland, R.; Davidson, A.E.; Tallantyre, E.C.; Robertson, N.P.; Wise, R.G.; et al. Comparing MRI metrics to quantify white matter microstructural damage in multiple sclerosis. Hum. Brain Mapp. 2019, 40, 2917-2932. [CrossRef] [PubMed]

35. Chang, E.H.; Argyelan, M.; Aggarwal, M.; Chandon, T.S.; Karlsgodt, K.H.; Mori, S.; Malhotra, A.K. Diffusion tensor imaging measures of white matter compared to myelin basic protein immunofluorescence in tissue cleared intact brains. Data Brief 2017, 10, 438-443. [CrossRef] [PubMed]

36. Moll, N.M.; Rietsch, A.M.; Thomas, S.; Ransohoff, A.J.; Lee, J.C.; Fox, R.; Chang, A.; Ransohoff, R.M.; Fisher, E. Multiple sclerosis normal-appearing white matter: Pathology-imaging correlations. Ann. Neurol. 2011, 70, 764-773. [CrossRef] [PubMed]

37. O'Muircheartaigh, J.; Vavasour, I.; Ljungberg, E.; Li, D.K.B.; Rauscher, A.; Levesque, V.; Garren, H.; Clayton, D.; Tam, R.; Traboulsee, A.; et al. Quantitative neuroimaging measures of myelin in the healthy brain and in multiple sclerosis. Hum. Brain Mapp. 2019, 40, 2104-2116. [CrossRef]

38. Fieremans, E.; Jensen, J.H.; Helpern, J.A. White matter characterization with diffusional kurtosis imaging. NeuroImage 2011, 58, 177-188. [CrossRef]

39. Wang, Y.; Sun, P.; Wang, Q.; Trinkaus, K.; Schmidt, R.E.; Naismith, R.T.; Cross, A.H.; Song, S.K. Differentiation and quantification of inflammation, demyelination and axon injury or loss in multiple sclerosis. Brain J. Neurol. 2015, 138 Pt 5, 1223-1238. [CrossRef]

40. Gatto, R.G.; Mustafi, S.M.; Amin, M.Y.; Mareci, T.H.; Wu, Y.C.; Magin, R.L. Neurite orientation dispersion and density imaging can detect presymptomatic axonal degeneration in the spinal cord of ALS mice. Funct. Neurol. 2018, 33, 155-163.

41. Margoni, M.; Petracca, M.; Schiavi, S.; Fabian, M.; Miller, A.; Lublin, F.D.; Inglese, M. Axonal water fraction as marker of white matter injury in primary-progressive multiple sclerosis: A longitudinal study. Eur. J. Neurol. 2019, 26, 1068-1074. [CrossRef] [PubMed]

42. Schiavi, S.; Petracca, M.; Sun, P.; Fleysher, L.; Cocozza, S.; El Mendili, M.M.; Signori, A.; Babb, J.S.; Podranski, K.; Song, S.K.; et al. Non-invasive quantification of inflammation, axonal and myelin injury in multiple sclerosis. Brain J. Neurol. 2021, 144, 213-223. [CrossRef] [PubMed]

43. Andersen, K.W.; Lasič, S.; Lundell, H.; Nilsson, M.; Topgaard, D.; Sellebjerg, F.; Szczepankiewicz, F.; Siebner, H.R.; Blinkenberg, M.; Dyrby, T.B. Disentangling white-matter damage from physiological fibre orientation dispersion in multiple sclerosis. Brain Commun. 2020, 2, fcaa077. [CrossRef]

44. Calamante, F. The seven deadly sins of measuring brain structural connectivity using diffusion mri streamlines fibre-tracking. Diagnostics 2019, 9, 115. [CrossRef]

45. Gatto, R.G.; Weissmann, C.; Amin, M.; Finkielsztein, A.; Sumagin, R.; Mareci, T.H.; Uchitel, O.D.; Magin, R.L. Assessing neuraxial microstructural changes in a transgenic mouse model of early stage Amyotrophic Lateral Sclerosis by ultra-high field MRI and diffusion tensor metrics. Anim. Models Exp. Med. 2020, 3, 117-129. [CrossRef] [PubMed]

46. Gatto, R.G. Molecular and microstructural biomarkers of neuroplasticity in neurodegenerative disorders through preclinical and diffusion magnetic resonance imaging studies. J. Integr. Neurosci. 2020, 19, 571-592. [CrossRef]

47. Tomassini, V.; Matthews, P.M.; Thompson, A.J.; Fuglø, D.; Geurts, J.J.; Johansen-Berg, H.; Jones, D.K.; Rocca, M.A.; Wise, R.G.; Barkhof, F.; et al. Neuroplasticity and functional recovery in multiple sclerosis. Nat. Rev. Neurol. 2012, 8, 635-646. [CrossRef]

48. Calabrese, M.; Filippi, M.; Gallo, P. Cortical lesions in multiple sclerosis. Nat. Rev. Neurol. 2010, 6, 438-444. [CrossRef] [PubMed]

49. Filippi, M.; Rocca, M.A.; Ciccarelli, O.; De Stefano, N.; Evangelou, N.; Kappos, L.; Rovira, A.; Sastre-Garriga, J.; Tintorè, M.; Frederiksen, J.L.; et al. MRI criteria for the diagnosis of multiple sclerosis: MAGNIMS consensus guidelines. Lancet Neurol. 2016, 15, 292-303. [CrossRef]

50. Cocozza, S.; Cosottini, M.; Signori, A.; Fleysher, L.; El Mendili, M.M.; Lublin, F.; Inglese, M.; Roccatagliata, L. A clinically feasible 7-Tesla protocol for the identification of cortical lesions in Multiple Sclerosis. Eur. Radiol. 2020, 30, 4586-4594. [CrossRef]

51. Geurts, J.J.; Pouwels, P.J.; Uitdehaag, B.M.; Polman, C.H.; Barkhof, F.; Castelijns, J.A. Intracortical lesions in multiple sclerosis: Improved detection with 3D double inversion-recovery MR imaging. Radiology 2005, 236, 254-260. [CrossRef] [PubMed]

52. Nelson, F.; Poonawalla, A.; Hou, P.; Wolinsky, J.S.; Narayana, P.A. 3D MPRAGE improves classification of cortical lesions in multiple sclerosis. Mult. Scler. J. 2008, 14, 1214-1219. [CrossRef] [PubMed]

53. Sethi, V.; Yousry, T.A.; Muhlert, N.; Ron, M.; Golay, X.; Wheeler-Kingshott, C.; Miller, D.H.; Chard, D.T. Improved detection of cortical MS lesions with phase-sensitive inversion recovery MRI. J. Neurol. Neurosurg. Psychiatry 2012, 83, 877-882. [CrossRef] [PubMed]

54. Rovira, À.; Wattjes, M.P.; Tintoré, M.; Tur, C.; Yousry, T.A.; Sormani, M.P.; De Stefano, N.; Filippi, M.; Auger, C.; Rocca, M.A.; et al. Evidence-based guidelines: MAGNIMS consensus guidelines on the use of MRI in multiple sclerosis-clinical implementation in the diagnostic process. Nat. Rev. Neurol. 2015, 11, 471-482. [CrossRef] [PubMed]

55. Wattjes, M.P.; Rovira, À.; Miller, D.; Yousry, T.A.; Sormani, M.P.; de Stefano, M.P.; Tintoré, M.; Auger, C.; Tur, C.; Filippi, M.; et al. Evidence-based guidelines: MAGNIMS consensus guidelines on the use of MRI in multiple sclerosis-Establishing disease prognosis and monitoring patients. Nat. Rev. Neurol. 2015, 11, 597-606. [CrossRef] [PubMed] 
56. Calabrese, M.; Agosta, F.; Rinaldi, F.; Mattisi, I.; Grossi, P.; Favaretto, A.; Atzori, M.; Bernardi, V.; Barachino, L.; Rinaldi, L.; et al. Cortical lesions and atrophy associated with cognitive impairment in relapsing-remitting multiple sclerosis. Arch. Neurol. 2009, 66, 1144-1150. [CrossRef]

57. Roosendaal, S.D.; Moraal, B.; Pouwels, P.J.; Vrenken, H.; Castelijns, J.A.; Barkhof, F.; Geurts, J.J. Accumulation of cortical lesions in MS: Relation with cognitive impairment. Mult. Scler. J. 2009, 15, 708-714. [CrossRef]

58. van de Pavert, S.H.; Muhlert, N.; Sethi, V.; Wheeler-Kingshott, C.A.; Ridgway, G.R.; Geurts, J.J.; Ron, M.; Yousry, T.A.; Thompson, A.J.; Miller, D.H.; et al. DIR-visible grey matter lesions and atrophy in multiple sclerosis: Partners in crime? J. Neurol. Neurosurg. Psychiatry 2016, 87, 461-467. [CrossRef]

59. Papadopoulou, A.; Müller-Lenke, N.; Naegelin, Y.; Kalt, G.; Bendfeldt, K.; Kuster, P.; Stoecklin, M.; Gass, A.; Sprenger, T.; Radue, E.W.; et al. Contribution of cortical and white matter lesions to cognitive impairment in multiple sclerosis. Mult. Scler. J. 2013, 19, 1290-1296. [CrossRef]

60. Geurts, J.J.; Barkhof, F. Grey matter pathology in multiple sclerosis. Lancet Neurol. 2008, 7, 841-851. [CrossRef]

61. Davies, G.R.; Ramió-Torrentà, L.; Hadjiprocopis, A.; Chard, D.T.; Griffin, C.M.; Rashid, W.; Barker, G.J.; Kapoor, R.; Thompson, A.J.; Miller, D.H. Evidence for grey matter MTR abnormality in minimally disabled patients with early relapsing-remitting multiple sclerosis. J. Neurol. Neurosurg. Psychiatry 2004, 75, 998-1002. [CrossRef]

62. Pontillo, G.; Petracca, M.; Monti, S.; Quarantelli, M.; Criscuolo, C.; Lanzillo, R.; Tedeschi, E.; Elefante, A.; Brescia Morra, V.; Brunetti, A.; et al. Unraveling deep gray matter atrophy. iron and myelin changes in Multiple Sclerosis. Am. J. Neuroradiol. 2021, in press.

63. Pontillo, G.; Cocozza, S.; Lanzillo, R.; Russo, C.; Stasi, M.D.; Paolella, C.; Vola, E.A.; Criscuolo, C.; Borrelli, P.; Palma, G.; et al. Determinants of deep gray matter atrophy in multiple sclerosis: A multimodal MRI study. Am. J. Neuroradiol. 2019, 40, 99-106. [CrossRef]

64. Vrenken, H.; Pouwels, P.J.; Geurts, J.J.; Knol, D.L.; Polman, C.H.; Barkhof, F.; Castelijns, J.A. Altered diffusion tensor in multiple sclerosis normal-appearing brain tissue: Cortical diffusion changes seem related to clinical deterioration. J. Magn. Reson. Imaging JMRI 2006, 23, 628-636. [CrossRef]

65. Deloire, M.S.; Salort, E.; Bonnet, M.; Arimone, Y.; Boudineau, M.; Amieva, H.; Barroso, B.; Ouallet, J.C.; Pachai, C.; Galliaud, E.; et al. Cognitive impairment as marker of diffuse brain abnormalities in early relapsing remitting multiple sclerosis. J. Neurol. Neurosurg. Psychiatry 2005, 76, 519-526. [CrossRef] [PubMed]

66. McKeithan, L.J.; Lyttle, B.D.; Box, B.A.; O'Grady, K.P.; Dortch, R.D.; Conrad, B.N.; Thompson, L.M.; Rogers, B.P.; Newhouse, P.; Pawate, S.; et al. 7T quantitative magnetization transfer (qMT) of cortical gray matter in multiple sclerosis correlates with cognitive impairment. NeuroImage 2019, 203, 116190. [CrossRef] [PubMed]

67. Cassiano, M.T.; Lanzillo, R.; Alfano, B.; Costabile, T.; Comerci, M.; Prinster, A.; Moccia, M.; Megna, R.; Morra, V.B.; Quarantelli, M.; et al. Voxel-based analysis of gray matter relaxation rates shows different correlation patterns for cognitive impairment and physical disability in relapsing-remitting multiple sclerosis. Neuroimage Clin. 2020, 26, 102201. [CrossRef] [PubMed]

68. Lommers, E.; Guillemin, C.; Reuter, G.; Fouarge, E.; Delrue, G.; Collette, F.; Degueldre, C.; Balteau, E.; Maquet, P.; Phillips, C. Voxel-Based quantitative MRI reveals spatial patterns of grey matter alteration in multiple sclerosis. Hum. Brain Mapp. 2021, 42, 1003-1012. [CrossRef] [PubMed]

69. Steenwijk, M.D.; Vrenken, H.; Jonkman, L.E.; Daams, M.; Geurts, J.J.; Barkhof, F.; Pouwels, P.J. High-resolution T1-relaxation time mapping displays subtle, clinically relevant, gray matter damage in long-standing multiple sclerosis. Mult. Scler. J. 2016, 22, 1279-1288. [CrossRef] [PubMed]

70. Llufriu, S.; Martinez-Heras, E.; Fortea, J.; Blanco, Y.; Berenguer, J.; Gabilondo, I.; Ibarretxe-Bilbao, N.; Falcon, C.; Sepulveda, M.; Sola-Valls, N.; et al. Cognitive functions in multiple sclerosis: Impact of gray matter integrity. Mult. Scler. J. 2014, 20, 424-432. [CrossRef]

71. Bester, M.; Jensen, J.H.; Babb, J.S.; Tabesh, A.; Miles, L.; Herbert, J.; Grossman, R.I.; Inglese, M. Non-Gaussian diffusion MRI of gray matter is associated with cognitive impairment in multiple sclerosis. Mult. Scler. J. 2015, 21, 935-944. [CrossRef]

72. Fujiwara, E.; Kmech, J.A.; Cobzas, D.; Sun, H.; Seres, P.; Blevins, G.; Wilman, A.H. Cognitive implications of deep gray matter iron in multiple sclerosis. Am. J. Neuroradiol. 2017, 38, 942-948. [CrossRef]

73. Louapre, C.; Govindarajan, S.T.; Giannì, C.; Madigan, N.; Nielsen, A.S.; Sloane, J.A.; Kinkel, R.P.; Mainero, C. The association between intra- and juxta-cortical pathology and cognitive impairment in multiple sclerosis by quantitative $\mathrm{T}(2)^{*}$ mapping at $7 \mathrm{~T}$ MRI. Neuroimage Clin. 2016, 12, 879-886. [CrossRef] [PubMed]

74. Moccia, M.; de Stefano, N.; Barkhof, F. Imaging outcome measures for progressive multiple sclerosis trials. Mult. Scler. J. 2017, 23, 1614-1626. [CrossRef] [PubMed]

75. Moccia, M.; Lanzillo, R.; Palladino, R.; Chang, K.C.; Costabile, T.; Russo, C.; De Rosa, A.; Carotenuto, A.; Saccà, F.; Maniscalco, G.T.; et al. Cognitive impairment at diagnosis predicts 10-year multiple sclerosis progression. Mult. Scler. J. 2016, 22, 659-667. [CrossRef] [PubMed]

76. Govindarajan, S.T.; Pan, R.; Krupp, L.; Charvet, L.; Duong, T.Q. Gray matter morphometry correlates with attentional efficiency in young-adult multiple sclerosis. Brain Sci. 2021, 11, 80. [CrossRef] 
77. Eijlers, A.J.C.; van Geest, Q.; Dekker, I.; Steenwijk, M.D.; Meijer, K.A.; Hulst, H.E.; Barkhof, F.; Uitdehaag, B.M.J.; Schoonheim, M.M.; Geurts, J.J.G. Predicting cognitive decline in multiple sclerosis: A 5-year follow-up study. Brain J. Neurol. 2018, 141, 2605-2618. [CrossRef]

78. Pontillo, G.; Cocozza, S.; Di Stasi, M.; Carotenuto, A.; Paolella, C.; Cipullo, M.B.; Perillo, T.; Vola, E.A.; Russo, C.; Masullo, M.; et al. 2D linear measures of ventricular enlargement may be relevant markers of brain atrophy and long-term disability progression in multiple sclerosis. Eur. Radiol. 2020, 30, 3813-3822. [CrossRef]

79. El Mendili, M.M.; Petracca, M.; Podranski, K.; Fleysher, L.; Cocozza, S.; Inglese, M. SUITer: An automated method for improving segmentation of infratentorial structures at ultra-high-field MRI. J. Neuroimaging Off. J. Am. Soc. Neuroimaging 2020, 30, 28-39. [CrossRef]

80. Burggraaff, J.; Liu, Y.; Prieto, J.C.; Simoes, J.; de Sitter, A.; Ruggieri, S.; Brouwer, I.; Lissenberg-Witte, B.I.; Rocca, M.A.; Valsasina, P.; et al. Manual and automated tissue segmentation confirm the impact of thalamus atrophy on cognition in multiple sclerosis: A multicenter study. Neuroimage Clin. 2021, 29, 102549. [CrossRef]

81. Capone, F.; Collorone, S.; Cortese, R.; Di Lazzaro, V.; Moccia, M. Fatigue in multiple sclerosis: The role of thalamus. Mult. Scler. J. 2020, 26, 6-16. [CrossRef] [PubMed]

82. Lorefice, L.; Carta, E.; Frau, J.; Contu, F.; Casaglia, E.; Coghe, G.; Barracciu, M.A.; Cocco, E.; Fenu, G. The impact of deep grey matter volume on cognition in multiple sclerosis. Mult. Scler. Relat. Disord. 2020, 45, 102351. [CrossRef] [PubMed]

83. Bergsland, N.; Benedict, R.H.B.; Dwyer, M.G.; Fuchs, T.A.; Jakimovski, D.; Schweser, F.; Tavazzi, E.; Weinstock-Guttman, B.; Zivadinov, R. Thalamic nuclei volumes and their relationships to neuroperformance in multiple sclerosis: A cross-sectional structural MRI study. J. Magn. Reson. Imaging JMRI 2021, 53, 731-739. [CrossRef]

84. Pontillo, G.; Petracca, M.; Cocozza, S.; Brunetti, A. The development of subcortical gray matter atrophy in multiple sclerosis: One size does not fit all. Am. J. Neuroradiol. 2020, 41, E80-E81. [CrossRef] [PubMed]

85. Ruggieri, S.; Petracca, M.; Miller, A.; Krieger, S.; Ghassemi, R.; Bencosme, Y.; Riley, C.; Howard, J.; Lublin, F.; Inglese, M. Association of deep gray matter damage with cortical and spinal cord degeneration in primary progressive multiple sclerosis. JAMA Neurol. 2015, 72, 1466-1474. [CrossRef] [PubMed]

86. Bassett, D.S.; Bullmore, E.T. Human brain networks in health and disease. Curr. Opin. Neurol. 2009, 22, 340-347. [CrossRef] [PubMed]

87. Fornito, A.; Bullmore, E.T. Connectomics: A new paradigm for understanding brain disease. Eur. Neuropsychopharmacol. J. Eur. Coll. Neuropsychopharmacol. 2015, 25, 733-748. [CrossRef] [PubMed]

88. Liu, Y.; Duan, Y.; Dong, H.; Barkhof, F.; Li, K.; Shu, N. Disrupted Module Efficiency of Structural and Functional Brain Connectomes in Clinically Isolated Syndrome and Multiple Sclerosis. Front. Hum. Neurosci. 2018, 12, 138. [CrossRef]

89. Shu, N.; Liu, Y.; Li, K.; Duan, Y.; Wang, J.; Yu, C.; Dong, H.; Ye, J.; He, Y. Diffusion tensor tractography reveals disrupted topological efficiency in white matter structural networks in multiple sclerosis. Cerebral Cortex 2011, 21, 2565-2577. [CrossRef]

90. Shu, N.; Duan, Y.; Huang, J.; Ren, Z.; Liu, Z.; Dong, H.; Barkhof, F.; Li, K.; Liu, Y. Progressive brain rich-club network disruption from clinically isolated syndrome towards multiple sclerosis. Neuroimage Clin. 2018, 19, 232-239. [CrossRef] [PubMed]

91. Charalambous, T.; Tur, C.; Prados, F.; Kanber, B.; Chard, D.T.; Ourselin, S.; Clayden, J.D.; Wheeler-Kingshott, C.A.M.G.; Thompson, A.J.; Toosy, A.T. Structural network disruption markers explain disability in multiple sclerosis. J. Neurol. Neurosurg. Psychiatry 2019, 90, 219-226. [CrossRef]

92. Llufriu, S.; Martinez-Heras, E.; Solana, E.; Sola-Valls, N.; Sepulveda, M.; Blanco, Y.; Martinez-Lapiscina, E.H.; Andorra, M.; Villoslada, P.; Prats-Galino, A.; et al. Structural networks involved in attention and executive functions in multiple sclerosis. Neuroimage Clin. 2017, 13, 288-296. [CrossRef] [PubMed]

93. Chard, D.T.; Alahmadi, A.A.S.; Audoin, B.; Charalambous, T.; Enzinger, C.; Hulst, H.E.; Rocca, M.A.; Rovira, À.; Sastre-Garriga, J.; Schoonheim, M.M.; et al. Mind the gap: From neurons to networks to outcomes in multiple sclerosis. Nat. Rev. Neurol. 2021. [CrossRef] [PubMed]

94. Steenwijk, M.D.; Geurts, J.J.; Daams, M.; Tijms, B.M.; Wink, A.M.; Balk, L.J.; Tewarie, P.K.; Uitdehaag, B.M.; Barkhof, F.; Vrenken, H.; et al. Cortical atrophy patterns in multiple sclerosis are non-random and clinically relevant. Brain J. Neurol. 2016, 139 Pt 1, 115-126. [CrossRef]

95. Rimkus, C.M.; Schoonheim, M.M.; Steenwijk, M.D.; Vrenken, H.; Eijlers, A.J.; Killestein, J.; Wattjes, M.P.; Leite, C.C.; Barkhof, F.; Tijms, B.M. Gray matter networks and cognitive impairment in multiple sclerosis. Mult. Scler. J. 2019, 25, 382-391. [CrossRef]

96. Tewarie, P.; Steenwijk, M.D.; Tijms, B.M.; Daams, M.; Balk, L.J.; Stam, C.J.; Uitdehaag, B.M.; Polman, C.H.; Geurts, J.J.; Barkhof, F.; et al. Disruption of structural and functional networks in long-standing multiple sclerosis. Hum. Brain Mapp. 2014, 35, 5946-5961. [CrossRef]

97. van den Heuvel, M.P.; Hulshoff Pol, H.E. Exploring the brain network: A review on resting-state fMRI functional connectivity. Eur. Neuropsychopharmacol. J. Eur. Coll. Neuropsychopharmacol. 2010, 20, 519-534. [CrossRef] [PubMed]

98. Au Duong, M.V.; Audoin, B.; Boulanouar, K.; Ibarrola, D.; Malikova, I.; Confort-Gouny, S.; Celsis, P.; Pelletier, J.; Cozzone, P.J.; Ranjeva, J.P. Altered functional connectivity related to white matter changes inside the working memory network at the very early stage of MS. J. Cereb. Blood Flow Metab. Off. J. Int. Soc. Cereb. Blood Flow Metab. 2005, 25, 1245-1253. [CrossRef]

99. Au Duong, M.V.; Boulanouar, K.; Audoin, B.; Treseras, S.; Ibarrola, D.; Malikova, I.; Confort-Gouny, S.; Celsis, P.; Pelletier, J.; Cozzone, P.J.; et al. Modulation of effective connectivity inside the working memory network in patients at the earliest stage of multiple sclerosis. NeuroImage 2005, 24, 533-538. [CrossRef] 
100. Audoin, B.; Ibarrola, D.; Ranjeva, J.P.; Confort-Gouny, S.; Malikova, I.; Ali-Chérif, A.; Pelletier, J.; Cozzone, P. Compensatory cortical activation observed by fMRI during a cognitive task at the earliest stage of MS. Hum. Brain Mapp. 2003, 20, 51-58. [CrossRef]

101. Colorado, R.A.; Shukla, K.; Zhou, Y.; Wolinsky, J.S.; Narayana, P.A. Multi-task functional MRI in multiple sclerosis patients without clinical disability. NeuroImage 2012, 59, 573-581. [CrossRef] [PubMed]

102. Mainero, C.; Caramia, F.; Pozzilli, C.; Pisani, A.; Pestalozza, I.; Borriello, G.; Bozzao, L.; Pantano, P. fMRI evidence of brain reorganization during attention and memory tasks in multiple sclerosis. NeuroImage 2004, 21, 858-867. [CrossRef]

103. Staffen, W.; Mair, A.; Zauner, H.; Unterrainer, J.; Niederhofer, H.; Kutzelnigg, A.; Ritter, S.; Golaszewski, S.; Iglseder, B.; Ladurner, G. Cognitive function and fMRI in patients with multiple sclerosis: Evidence for compensatory cortical activation during an attention task. Brain J. Neurol. 2002, 125 Pt 6, 1275-1282. [CrossRef]

104. Roosendaal, S.D.; Schoonheim, M.M.; Hulst, H.E.; Sanz-Arigita, E.J.; Smith, S.M.; Geurts, J.J.; Barkhof, F. Resting state networks change in clinically isolated syndrome. Brain J. Neurol. 2010, 133 Pt 6, 1612-1621. [CrossRef]

105. Bonavita, S.; Gallo, A.; Sacco, R.; Corte, M.D.; Bisecco, A.; Docimo, R.; Lavorgna, L.; Corbo, D.; Costanzo, A.D.; Tortora, F.; et al. Distributed changes in default-mode resting-state connectivity in multiple sclerosis. Mult. Scler. J. 2011, 17, 411-422. [CrossRef] [PubMed]

106. Rocca, M.A.; Valsasina, P.; Absinta, M.; Riccitelli, G.; Rodegher, M.E.; Misci, P.; Rossi, P.; Falini, A.; Comi, G.; Filippi, M. Default-mode network dysfunction and cognitive impairment in progressive MS. Neurology 2010, 74, 1252-1259. [CrossRef] [PubMed]

107. Zhu, Y.; Huang, M.; Zhao, Y.; Pei, Y.; Wang, Y.; Wang, L.; He, T.; Zhou, F.; Zeng, X. Local functional connectivity of patients with acute and remitting multiple sclerosis: A Kendall's coefficient of concordance- and coherence-regional homogeneity study. Medicine 2020, 99, e22860. [CrossRef] [PubMed]

108. Petracca, M.; Saiote, C.; Bender, H.A.; Arias, F.; Farrell, C.; Magioncalda, P.; Martino, M.; Miller, A.; Northoff, G.; Lublin, F.; et al. Synchronization and variability imbalance underlie cognitive impairment in primary-progressive multiple sclerosis. Sci. Rep. 2017, 7, 46411. [CrossRef] [PubMed]

109. Cirillo, S.; Rocca, M.A.; Ghezzi, A.; Valsasina, P.; Moiola, L.; Veggiotti, P.; Amato, M.P.; Comi, G.; Falini, A.; Filippi, M. Abnormal cerebellar functional MRI connectivity in patients with paediatric multiple sclerosis. Mult. Scler. J. 2016, 22, 292-301. [CrossRef]

110. Sbardella, E.; Upadhyay, N.; Tona, F.; Prosperini, L.; De Giglio, L.; Petsas, N.; Pozzilli, C.; Pantano, P. Dentate nucleus connectivity in adult patients with multiple sclerosis: Functional changes at rest and correlation with clinical features. Mult. Scler. J. 2017, 23, 546-555. [CrossRef] [PubMed]

111. Cocozza, S.; Pontillo, G.; Russo, C.; Russo, C.V.; Costabile, T.; Pepe, A.; Tedeschi, E.; Lanzillo, R.; Brescia Morra, V.; Brunetti, A.; et al. Cerebellum and cognition in progressive MS patients: Functional changes beyond atrophy? J. Neurol. 2018, 265, 2260-2266. [CrossRef] [PubMed]

112. Cocozza, S. Editorial: The Cerebellum: From Vascular Disease to Neurodegeneration. Front. Neurol. 2021, 12, 657376. [CrossRef]

113. Cocozza, S.; Costabile, T.; Pontillo, G.; Lieto, M.; Russo, C.; Radice, L.; Pane, C.; Filla, A.; Brunetti, A.; Saccà, F. Cerebellum and cognition in Friedreich ataxia: A voxel-based morphometry and volumetric MRI study. J. Neurol. 2020, 267, 350-358. [CrossRef]

114. Cocozza, S.; Saccà, F.; Cervo, A.; Marsili, A.; Russo, C.V.; Giorgio, S.M.; De Michele, G.; Filla, A.; Brunetti, A.; Quarantelli, M. Modifications of resting state networks in spinocerebellar ataxia type 2. Mov. Disord. Off. J. Mov. Disord. Soc. 2015, 30, 1382-1390. [CrossRef] [PubMed]

115. De Michele, G.; Salvatore, E.; Cocozza, S.; Filla, A.; Santorelli, F.M. Of cognition and cerebellum in SCA48. Neurogenetics 2020, 21, 145-146. [CrossRef] [PubMed]

116. Mormina, E.; Petracca, M.; Bommarito, G.; Piaggio, N.; Cocozza, S.; Inglese, M. Cerebellum and neurodegenerative diseases: Beyond conventional magnetic resonance imaging. World J. Radiol. 2017, 9, 371-388. [CrossRef]

117. Jehna, M.; Langkammer, C.; Wallner-Blazek, M.; Neuper, C.; Loitfelder, M.; Ropele, S.; Fuchs, S.; Khalil, M.; Pluta-Fuerst, A.; Fazekas, F.; et al. Cognitively preserved MS patients demonstrate functional differences in processing neutral and emotional faces. Brain Imaging Behav. 2011, 5, 241-251. [CrossRef]

118. Passamonti, L.; Cerasa, A.; Liguori, M.; Gioia, M.C.; Valentino, P.; Nisticò, R.; Quattrone, A.; Fera, F. Neurobiological mechanisms underlying emotional processing in relapsing-remitting multiple sclerosis. Brain J. Neurol. 2009, 132 Pt 12, 3380-3391. [CrossRef]

119. Cader, S.; Cifelli, A.; Abu-Omar, Y.; Palace, J.; Matthews, P.M. Reduced brain functional reserve and altered functional connectivity in patients with multiple sclerosis. Brain J. Neurol. 2006, 129 Pt 2, 527-537. [CrossRef]

120. Bauckneht, M.; Capitanio, S.; Raffa, S.; Roccatagliata, L.; Pardini, M.; Lapucci, C.; Marini, C.; Sambuceti, G.; Inglese, M.; Gallo, P.; et al. Molecular imaging of multiple sclerosis: From the clinical demand to novel radiotracers. EJNMMI Radiopharm. Chem. 2019, 4, 6. [CrossRef] [PubMed]

121. Banati, R.B.; Newcombe, J.; Gunn, R.N.; Cagnin, A.; Turkheimer, F.; Heppner, F.; Price, G.; Wegner, F.; Giovannoni, G.; Miller, D.H.; et al. The peripheral benzodiazepine binding site in the brain in multiple sclerosis: Quantitative in vivo imaging of microglia as a measure of disease activity. Brain J. Neurol. 2000, 123 Pt 11, 2321-2337. [CrossRef]

122. Debruyne, J.C.; Versijpt, J.; Van Laere, K.J.; De Vos, F.; Keppens, J.; Strijckmans, K.; Achten, E.; Slegers, G.; Dierckx, R.A.; Korf, J.; et al. PET visualization of microglia in multiple sclerosis patients using [ ${ }^{11}$ C]PK11195. Eur. J. Neurol. 2003, 10, 257-264. [CrossRef] 
123. Politis, M.; Giannetti, P.; Su, P.; Turkheimer, F.; Keihaninejad, S.; Wu, K.; Waldman, A.; Malik, O.; Matthews, P.M.; Reynolds, R.; et al. Increased PK11195 PET binding in the cortex of patients with MS correlates with disability. Neurology 2012, 79, 523-530. [CrossRef]

124. Rissanen, E.; Tuisku, J.; Rokka, J.; Paavilainen, T.; Parkkola, R.; Rinne, J.O.; Airas, L. In vivo detection of diffuse inflammation in secondary progressive multiple sclerosis using PET imaging and the radioligand ${ }^{11}$ C-PK11195. J. Nucl. Med. Off. Publ. Soc. Nucl. Med. 2014, 55, 939-944. [CrossRef] [PubMed]

125. Vas, A.; Shchukin, Y.; Karrenbauer, V.D.; Cselényi, Z.; Kostulas, K.; Hillert, J.; Savic, I.; Takano, A.; Halldin, C.; Gulyás, B. Functional neuroimaging in multiple sclerosis with radiolabelled glia markers: Preliminary comparative PET studies with $\left[{ }^{11}\right.$ C]vinpocetine and $\left[{ }^{11}\right.$ C]PK11195 in patients. J. Neurol. Sci. 2008, 264, 9-17. [CrossRef] [PubMed]

126. Vowinckel, E.; Reutens, D.; Becher, B.; Verge, G.; Evans, A.; Owens, T.; Antel, J.P. PK11195 binding to the peripheral benzodiazepine receptor as a marker of microglia activation in multiple sclerosis and experimental autoimmune encephalomyelitis. J. Neurosci. Res. 1997, 50, 345-353. [CrossRef]

127. Giannetti, P.; Politis, M.; Su, P.; Turkheimer, F.E.; Malik, O.; Keihaninejad, S.; Wu, K.; Waldman, A.; Reynolds, R.; Nicholas, R.; et al. Increased PK11195-PET binding in normal-appearing white matter in clinically isolated syndrome. Brain J. Neurol. 2015, 138 Pt 1, 110-119. [CrossRef]

128. Sucksdorff, M.; Matilainen, M.; Tuisku, J.; Polvinen, E.; Vuorimaa, A.; Rokka, J.; Nylund, M.; Rissanen, E.; Airas, L. Brain TSPO-PET predicts later disease progression independent of relapses in multiple sclerosis. Brain J. Neurol. 2020, 143, 3318-3330. [CrossRef]

129. Herranz, E.; Giannì, C.; Louapre, C.; Treaba, C.A.; Govindarajan, S.T.; Ouellette, R.; Loggia, M.L.; Sloane, J.A.; Madigan, N.; Izquierdo-Garcia, D.; et al. Neuroinflammatory component of gray matter pathology in multiple sclerosis. Ann. Neurol. 2016, 80, 776-790. [CrossRef] [PubMed]

130. Sokoloff, L. Energetics of functional activation in neural tissues. Neurochem. Res. 1999, 24, 321-329. [CrossRef]

131. Freeman, L.; Garcia-Lorenzo, D.; Bottin, L.; Leroy, C.; Louapre, C.; Bodini, B.; Papeix, C.; Assouad, R.; Granger, B.; Tourbah, A.; et al. The neuronal component of gray matter damage in multiple sclerosis: A [ $\left.{ }^{11} \mathrm{C}\right]$ flumazenil positron emission tomography study. Ann. Neurol. 2015, 78, 554-567. [CrossRef]

132. Blinkenberg, M.; Mathiesen, H.K.; Tscherning, T.; Jønsson, A.; Svarer, C.; Holm, S.; Sellebjerg, F.; Paulson, O.B.; Hanson, L.G.; Sorensen, P.S. Cerebral metabolism, magnetic resonance spectroscopy and cognitive dysfunction in early multiple sclerosis: An exploratory study. Neurol. Res. 2012, 34, 52-58. [CrossRef] [PubMed]

133. Paulesu, E.; Perani, D.; Fazio, F.; Comi, G.; Pozzilli, C.; Martinelli, V.; Filippi, M.; Bettinardi, V.; Sirabian, G.; Passafiume, D.; et al. Functional basis of memory impairment in multiple sclerosis: A [ ${ }^{18}$ F]FDG PET study. NeuroImage 1996, 4, 87-96. [CrossRef]

134. Bajaj, A.; LaPlante, N.E.; Cotero, V.E.; Fish, K.M.; Bjerke, R.M.; Siclovan, T.; Tan Hehir, C.A. Identification of the protein target of myelin-binding ligands by immunohistochemistry and biochemical analyses. J. Histochem. Cytochem. Off. J. Histochem. Soc. 2013, 61, 19-30. [CrossRef]

135. Grecchi, E.; Veronese, M.; Bodini, B.; García-Lorenzo, D.; Battaglini, M.; Stankoff, B.; Turkheimer, F.E. Multimodal partial volume correction: Application to $\left[{ }^{11}\right.$ C]PIB PET/MRI myelin imaging in multiple sclerosis. J. Cereb. Blood Flow Metab. Off. J. Int. Soc. Cereb. Blood Flow Metab. 2017, 37, 3803-3817. [CrossRef] [PubMed]

136. Stankoff, B.; Freeman, L.; Aigrot, M.S.; Chardain, A.; Dollé, F.; Williams, A.; Galanaud, D.; Armand, L.; Lehericy, S.; Lubetzki, C.; et al. Imaging central nervous system myelin by positron emission tomography in multiple sclerosis using [methyl- $\left.{ }^{11} \mathrm{C}\right]-2-\left(4^{\prime}\right.$-methylaminophenyl)- 6-hydroxybenzothiazole. Ann. Neurol. 2011, 69, 673-680. [CrossRef] [PubMed]

137. Wang, Y.; Wu, C.; Caprariello, A.V.; Somoza, E.; Zhu, W.; Wang, C.; Miller, R.H. In vivo quantification of myelin changes in the vertebrate nervous system. J. Neurosci. Off. J. Soc. Neurosci. 2009, 29, 14663-14669. [CrossRef]

138. Pytel, V.; Matias-Guiu, J.A.; Matías-Guiu, J.; Cortés-Martínez, A.; Montero, P.; Moreno-Ramos, T.; Arrazola, J.; Carreras, J.L.; Cabrera-Martín, M.N. Amyloid PET findings in multiple sclerosis are associated with cognitive decline at 18 months. Mult. Scler. Relat. Disord. 2020, 39, 101926. [CrossRef]

139. Pietroboni, A.M.; Carandini, T.; Colombi, A.; Mercurio, M.; Ghezzi, L.; Giulietti, G.; Scarioni, M.; Arighi, A.; Fenoglio, C.; De Riz, M.A.; et al. Amyloid PET as a marker of normal-appearing white matter early damage in multiple sclerosis: Correlation with CSF $\beta$-amyloid levels and brain volumes. Eur. J. Nucl. Med. Mol. Imaging 2019, 46, 280-287. [CrossRef]

140. Bitsch, A.; Bruhn, H.; Vougioukas, V.; Stringaris, A.; Lassmann, H.; Frahm, J.; Brück, W. Inflammatory CNS demyelination: Histopathologic correlation with in vivo quantitative proton MR spectroscopy. Am. J. Neuroradiol. 1999, 20, $1619-1627$.

141. Lin, A.; Ross, B.D.; Harris, K.; Wong, W. Efficacy of proton magnetic resonance spectroscopy in neurological diagnosis and neurotherapeutic decision making. Neurorx J. Am. Soc. Exp. Neurother. 2005, 2, 197-214. [CrossRef]

142. De Stefano, N.; Matthews, P.M.; Antel, J.P.; Preul, M.; Francis, G.; Arnold, D.L. Chemical pathology of acute demyelinating lesions and its correlation with disability. Ann. Neurol. 1995, 38, 901-909. [CrossRef]

143. Narayana, P.A.; Doyle, T.J.; Lai, D.; Wolinsky, J.S. Serial proton magnetic resonance spectroscopic imaging, contrast-enhanced magnetic resonance imaging, and quantitative lesion volumetry in multiple sclerosis. Ann. Neurol. 1998, 43, 56-71. [CrossRef] [PubMed]

144. Rocca, M.A.; Mezzapesa, D.M.; Falini, A.; Ghezzi, A.; Martinelli, V.; Scotti, G.; Comi, G.; Filippi, M. Evidence for axonal pathology and adaptive cortical reorganization in patients at presentation with clinically isolated syndromes suggestive of multiple sclerosis. NeuroImage 2003, 18, 847-855. [CrossRef] 
145. Wattjes, M.P.; Harzheim, M.; Lutterbey, G.G.; Bogdanow, M.; Schild, H.H.; Träber, F. High field MR imaging and ${ }^{1}$ H-MR spectroscopy in clinically isolated syndromes suggestive of multiple sclerosis: Correlation between metabolic alterations and diagnostic MR imaging criteria. J. Neurol. 2008, 255, 56-63. [CrossRef] [PubMed]

146. Solanky, B.S.; John, N.A.; DeAngelis, F.; Stutters, J.; Prados, F.; Schneider, T.; Parker, R.A.; Weir, C.J.; Monteverdi, A.; Plantone, D.; et al. NAA is a marker of disability in secondary-progressive MS: A proton MR spectroscopic imaging study. Am. J. Neuroradiol. 2020, 41, 2209-2218. [CrossRef] [PubMed]

147. Azevedo, C.J.; Kornak, J.; Chu, P.; Sampat, M.; Okuda, D.T.; Cree, B.A.; Nelson, S.J.; Hauser, S.L.; Pelletier, D. In vivo evidence of glutamate toxicity in multiple sclerosis. Ann. Neurol. 2014, 76, 269-278. [CrossRef]

148. MacMillan, E.L.; Tam, R.; Zhao, Y.; Vavasour, I.M.; Li, D.K.; Oger, J.; Freedman, M.S.; Kolind, S.H.; Traboulsee, A.L. Progressive multiple sclerosis exhibits decreasing glutamate and glutamine over two years. Mult. Scler. J. 2016, 22, 112-116. [CrossRef]

149. Muhlert, N.; Atzori, M.; De Vita, E.; Thomas, D.L.; Samson, R.S.; Wheeler-Kingshott, C.A.; Geurts, J.J.; Miller, D.H.; Thompson, A.J.; Ciccarelli, O. Memory in multiple sclerosis is linked to glutamate concentration in grey matter regions. J. Neurol. Neurosurg. Psychiatry 2014, 85, 833-839. [CrossRef]

150. Sastre-Garriga, J.; Ingle, G.T.; Chard, D.T.; Ramió-Torrentà, L.; McLean, M.A.; Miller, D.H.; Thompson, A.J. Metabolite changes in normal-appearing gray and white matter are linked with disability in early primary progressive multiple sclerosis. Arch. Neurol. 2005, 62, 569-573. [CrossRef]

151. Srinivasan, R.; Sailasuta, N.; Hurd, R.; Nelson, S.; Pelletier, D. Evidence of elevated glutamate in multiple sclerosis using magnetic resonance spectroscopy at 3 T. Brain J. Neurol. 2005, 128 Pt 5, 1016-1025. [CrossRef]

152. Cawley, N.; Solanky, B.S.; Muhlert, N.; Tur, C.; Edden, R.A.; Wheeler-Kingshott, C.A.; Miller, D.H.; Thompson, A.J.; Ciccarelli, O. Reduced gamma-aminobutyric acid concentration is associated with physical disability in progressive multiple sclerosis. Brain J. Neurol. 2015, 138 Pt 9, 2584-2595. [CrossRef]

153. Droby, A.; Fleysher, L.; Petracca, M.; Podranski, K.; Xu, J.; Fabian, M.; Marjańska, M.; Inglese, M. Lower cortical gamma-aminobutyric acid level contributes to increased connectivity in sensory-motor regions in progressive MS. Mult. Scler. Relat. Disord. 2020, 43, 102183. [CrossRef] [PubMed]

154. Narayana, P.A. Magnetic resonance spectroscopy in the monitoring of multiple sclerosis. J. Neuroimaging Off. J. Am. Soc. Neuroimaging 2005, 15, 46s-57s. [CrossRef]

155. Kirov, I.I.; Tal, A.; Babb, J.S.; Herbert, J.; Gonen, O. Serial proton MR spectroscopy of gray and white matter in relapsing-remitting MS. Neurology 2013, 80, 39-46. [CrossRef] [PubMed]

156. Donadieu, M.; Le Fur, Y.; Lecocq, A.; Maudsley, A.A.; Gherib, S.; Soulier, E.; Confort-Gouny, S.; Pariollaud, F.; Ranjeva, M.P.; Pelletier, J.; et al. Metabolic voxel-based analysis of the complete human brain using fast 3D-MRSI: Proof of concept in multiple sclerosis. J. Magn. Reson. Imaging JMRI 2016, 44, 411-419. [CrossRef] [PubMed]

157. Petracca, M.; Fleysher, L.; Oesingmann, N.; Inglese, M. Sodium MRI of multiple sclerosis. NMR Biomed. $2016,29,153-161$. [CrossRef]

158. Trapp, B.D.; Stys, P.K. Virtual hypoxia and chronic necrosis of demyelinated axons in multiple sclerosis. Lancet Neurol. 2009, 8 , 280-291. [CrossRef]

159. Périer, O.; Grégoire, A. Electron microscopic features of multiple sclerosis lesions. Brain J. Neurol. 1965, 88, 937-952. [CrossRef] [PubMed]

160. Turski, P.A.; Perman, W.H.; Hald, J.K.; Houston, L.W.; Strother, C.M.; Sackett, J.F. Clinical and experimental vasogenic edema: In vivo sodium MR imaging. Work in progress. Radiology 1986, 160, 821-825. [CrossRef] [PubMed]

161. Brownlee, W.J.; Solanky, B.; Prados, F.; Yiannakas, M.; Da Mota, P.; Riemer, F.; Cardoso, M.J.; Ourselin, S.; Golay, X.; Gandini Wheeler-Kingshott, C.; et al. Cortical grey matter sodium accumulation is associated with disability and secondary progressive disease course in relapse-onset multiple sclerosis. J. Neurol. Neurosurg. Psychiatry 2019, 90, 755-760. [CrossRef] [PubMed]

162. Inglese, M.; Madelin, G.; Oesingmann, N.; Babb, J.S.; Wu, W.; Stoeckel, B.; Herbert, J.; Johnson, G. Brain tissue sodium concentration in multiple sclerosis: A sodium imaging study at 3 tesla. Brain J. Neurol. 2010, 133 Pt 3, 847-857. [CrossRef]

163. Maarouf, A.; Audoin, B.; Konstandin, S.; Rico, A.; Soulier, E.; Reuter, F.; Le Troter, A.; Confort-Gouny, S.; Cozzone, P.J.; Guye, M.; et al. Topography of brain sodium accumulation in progressive multiple sclerosis. Magma 2014, 27, 53-62. [CrossRef] [PubMed]

164. Maarouf, A.; Audoin, B.; Pariollaud, F.; Gherib, S.; Rico, A.; Soulier, E.; Confort-Gouny, S.; Guye, M.; Schad, L.; Pelletier, J.; et al. Increased total sodium concentration in gray matter better explains cognition than atrophy in MS. Neurology 2017, 88, 289-295. [CrossRef] [PubMed]

165. Paling, D.; Solanky, B.S.; Riemer, F.; Tozer, D.J.; Wheeler-Kingshott, C.A.; Kapoor, R.; Golay, X.; Miller, D.H. Sodium accumulation is associated with disability and a progressive course in multiple sclerosis. Brain J. Neurol. 2013, 136 Pt 7, 2305-2317. [CrossRef]

166. Zaaraoui, W.; Konstandin, S.; Audoin, B.; Nagel, A.M.; Rico, A.; Malikova, I.; Soulier, E.; Viout, P.; Confort-Gouny, S.; Cozzone, P.J.; et al. Distribution of brain sodium accumulation correlates with disability in multiple sclerosis: A cross-sectional 23Na MR imaging study. Radiology 2012, 264, 859-867. [CrossRef] [PubMed]

167. Petracca, M.; Vancea, R.O.; Fleysher, L.; Jonkman, L.E.; Oesingmann, N.; Inglese, M. Brain intra- and extracellular sodium concentration in multiple sclerosis: A 7 T MRI study. Brain J. Neurol. 2019, 139 Pt 3, 795-806. [CrossRef] 